78 巻 789 号 2012-5)

\title{
分散型エネルギーシステムにおける熱利用プロセスの 動的補償を用いたモデルベース性能監視*
}

涌井 徹也 ${ }^{* 1}$, 今泉 直樹 ${ }^{* 2}$, 横山 良平 ${ }^{* 1}$

\section{Model-Based Performance Monitoring with Dynamic Compensation for Heat Utilization Process in Distributed Energy System}

\author{
Tetsuya WAKUI ${ }^{* 1}$, Naoki IMAIZUMI and Ryohei YOKOYAMA \\ ${ }^{* 1}$ Osaka Prefecture University, Dept. of Mechanical Engineering \\ 1-1 Gakuen-cho, Naka-ku, Sakai, Osaka, 599-8531 Japan
}

\begin{abstract}
A model-based performance monitoring method for a heat utilization process in a distributed energy system is developed in this study. This performance monitoring has three components: a static input-output model for the target process, a dynamic compensation function, and a failure detection function. First, the static input-output model estimates the values of output process variables in response to the variations in measured values of input process variables. Then, the dynamic characteristics of the output process variables are provided by the dynamic compensation where they are indentified as first order lag elements. Finally, the estimated values of the output process variables, which consider the dynamic characteristics, are compared with the measured values of the output process variables in order to detect device failures. Through a numerical simulation for a heat utilization process in a gas engine cogeneration system that has a radiator with a considerable lag characteristic, the effectiveness of the developed performance monitoring method in a dynamic state is verified. The result shows the sufficiency of the estimation accuracy of the output process variables and the capability of detecting device failures, including the deterioration in the heat transfer performance in the radiator and heat exchanger, in a dynamic state.
\end{abstract}

Key Words : Monitoring, Model-Based Monitoring, Fault Detection, Heat Exchanger, Cogeneration, Distributed Generation, Energy Management

\section{1. 緒言}

高い省エネルギー性や経済性が期待できる分散型エネルギーシステムは，産業用，民生用に加えて家庭用とし ても普及が進みつつある. 今後さらに普及が進んだ場合に設備管理技術者が分散配置された各設備を常時監視す ることは，人材確保，費用などの点から現実的ではない，よって，性能低下を始めとした機器の種々の異常を検 出する監視機能, さらにはその要因を特定する診断機能を備えた上で, 設備管理技術者の手を介することなく自 律的に運転を行うことが重要になる. また，分散型エネルギーシステムによる省エネルギー性や経済性を向上さ せるためには，季節的・時間的に大きく変動するエネルギー需要量に応じて適切にシステムの運用を行う必要が ある。これまでに，エネルギー需要量予測，最適運用計画，および最適制御を統合した分散型エネルギーシステ ムのためのリアルタイム計算機援用システムが提案されている(1). 最適運用計画や最適制御はシステム構成機器 の性能に基づいて実行されるが，機器性能は季節変化や経年劣化などの影響を受けるため，リアルタイム計算機 援用システムでは性能監視も併せて行う必要がある. よって, 分散型エネルギーシステムのための監視・診断手 法を確立することで，今後の分散型エネルギーシステムのさらなる普及に大きく寄与できるものと考える.

エネルギーシステムおよび各種プロセスシステムの監視・診断手法については，これまでも多くの研究が行わ れてきており, Venkatasubramanian らはこれを定量的モデルに基づく方法 ${ }^{(2)}$, 定性的モデルに基づく方法 ${ }^{(3)}$ ，およ

\footnotetext{
*原稿受付 2011 年 10 月 31 日

*1 正員, 大阪府立大学大学院工学研究科（干599-8531 大阪府堺市中区学園町 1-1）

*2 学生員, 大阪府立大学大学院工学研究科

E-mail: wakui@ese.me.osakafu-u.ac.jp
} 
びプロセス履歴（過去の運転データ）に基づく方法 ${ }^{(4)} の 3$ つ分類整理している．定性的モデルに基づく方法の 代表的なものとして, パターン認識(5)，ニューラルネットワーク ${ }^{(6)}$, エキスパートシステム(7)などによる監視・診

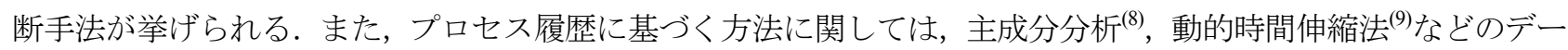
夕処理手法を用いた監視・診断手法が報告されている.これらの手法は対象の詳細な情報や解析モデルを使用せ ずに監視・診断を行えるという利点を持つが，最適運用計画・最適制御を行うために必要な機器性能の定量評価 を行うことができない，一方，計測值と解析モデルによる推定值との残差を用いて監視を行う定量的モデルに基 づく方法（モデルベース監視）によるならばこれが可能となり，さらには，機器に生じた異常の発生要因を解析 モデルを用いて説明することもできる，モデルベース監視に関しては，外気温度などの環境条件の変化に対応し た性能監視手法 ${ }^{(10),(11)}$, 光学式トルク計での軸トルク測定を併用した性能監視手法(12)などがこれまでに報告されて いるが，ガスタービンコンバインドサイクル発電所に代表される大規模集中型システムを対象としており，負荷 率などの運転条件の変化については十分な検討が行われていない，分散型エネルギーシステムの運転条件はエネ ルギー需要量の変動に応じて大きく変化することから，各運転条件において本来持つべき性能でシステムが運転 しているかどうかを監視することが重要になる.

以上を踏まえて筆者らは，分散型エネルギーシステムやプロセスシステムで広く用いられているシェルアンド チューブ式熱交換器を対象に，定常特性に着目した入出力モデルを用いたモデルベース性能監視手法を構築した (13). さらに, 数分オーダーの熱交換器の整定時間に相当する周期の変動を許容することで, 動的状態下でも性能 監視が行えることを明らかにした ${ }^{(14)}$ 。しかし，分散型エネルギーシステムのボトミングに配置される熱利用プロ セスは, 熱源と複数の温度制御ループ（熱交換器と制御機器からなる制御系）より構成され，運転条件によって は制御対象である熱交換器の応答に関する時間遅れが大きくなりうる，そこで，本論文では複数の機器から構成 される分散型エネルギーシステムの熱利用プロセスに対して, 動的状態に対応したモデルベース性能監視手法を 構築する. 具体的には, 対象プロセスにおける熱交換器の時間遅れ特性を一次遅れ系で近似し, 監視間隔分の応 答の時間遅れを入出力モデルで推定した出力プロセス值に反映させる動的補償を新たに導入する，その上で，民 生用ガスエンジンコージェネレーションシステムを対象とした数值シミュレーションによるケーススタディを通 して，構築したモデルベース性能監視手法の動的状態下での有効性を明らかにする.

\section{2. 動的補償を用いたモデルベース性能監視手法}

本論文で構築する動的補償を用いたモデルベース性能監視手法の概念図を図 1 に示す．まず，対象プロセスで 測定するプロセス值を, 入力として対象プロセスの運転条件を決定するもの（以後, 入力プロセス值）と出力と して入力プロセス值に応じて決定されるもの（以後，出力プロセス值）とに分類する．その上で，任意のサンプ リング時間で入力プロセス值 $\boldsymbol{P} \boldsymbol{V}_{\mathrm{in}}^{\mathrm{M}}$ と出力プロセス值 $\boldsymbol{P} \boldsymbol{V}_{\mathrm{out}}^{\mathrm{M}}$ を測定する. 測定したプロセス值には流量変動などに 起因するノイズが含まれうるため，任意に定める平均化処理時間 $\Delta t$ ごとに単純平均值を算出し，それぞれを時刻 $t$ における $\overline{\boldsymbol{P V}}_{\mathrm{in}, t}^{\mathrm{M}}, \overline{\boldsymbol{P V}}_{\mathrm{out}, t}^{\mathrm{M}}$ とする. 次に, 対象プロセスの構成機器に関する定常状態での物質収支式, 熱収支式, 構成機器の接続条件, 制御条件, 対象プロセスの境界条件 $\left(\overline{\boldsymbol{P V}}_{\mathrm{in}, t}^{\mathrm{M}}\right.$ が相当) から構成される入出力モデルを用い て, $\overline{\boldsymbol{P V}}_{\mathrm{in}, t}^{\mathrm{M}}$ に応じた定常状態での出力プロセス值 $\boldsymbol{P} \boldsymbol{V}_{\mathrm{out}, t}^{\mathrm{S}}$ を推定する. 入出力モデルは, $\overline{\boldsymbol{P V}}_{\mathrm{in}, t}^{\mathrm{M}}$ と $\boldsymbol{P} \boldsymbol{V}_{\mathrm{out}, t}^{\mathrm{S}}$ を用いると

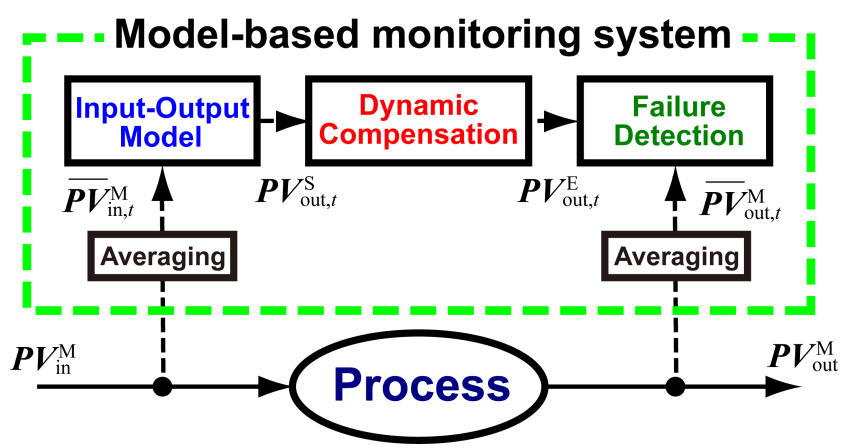

Fig. 1 Basic concept of model-based performance monitoring method with dynamic compensation 
次式に示す非線形連立代数方程式に帰着する.

$$
\boldsymbol{f}_{\mathrm{IO}}\left(\overline{\boldsymbol{P V}}_{\mathrm{in}, t}^{\mathrm{M}}, \boldsymbol{P} \boldsymbol{V}_{\mathrm{out}, t}^{\mathrm{S}}\right)=\mathbf{0}
$$

ここで， $\boldsymbol{f}_{\mathrm{IO}}$ ：入出力特性を表す方程式ベクトル．式(1)を数値的に解くことで $P V_{\mathrm{out}, t}^{\mathrm{S}}$ を算出する.

熱利用プロセスの特徵として, 熱容量や温水通過時間などに起因する熱交換器の応答に関する時間遅れが大き いことが挙げられる. 特に, 分散型エネルギーシステムではエネルギー需要量の変動に応じて運転条件が大きく 変化するため, 対象プロセスの定常状態に着目した入出力モデルでは, 出力プロセス值を動的状態下で正しく推 定できないことが考えられる，そこで本論文では，応答の時間遅れが大きな出力プロセス值に対して以下に示す 動的補償を適用する. まず，対象プロセスの平衡点からの微小変化に着目して，入力プロセス值の変化に対する 出力プロセス值の応答を表す伝達関数を導出し，その周波数特性を算出する．その上で，対象プロセスの時間遅 れ特性を一次遅れ系で近似して応答時定数を算出する. 一次遅れ系として近似した場合の応答時定数はカットオ フ周波数（極低周波数域での静的ゲインよりゲインが $3.01 \mathrm{~dB}$ 低下した時の周波数）より算出できる.また，応 答時定数は入力プロセス值によって変化する伝熱特性, 熱容量, および温水通過時間などの影響を受けるため, 入力プロセス值の関数として同定する. 時刻 $t$ における $l$ 番目の入力プロセス值の変化に対する $n$ 番目の出力プロ セス值の応答時定数 $T_{t}^{l, n}$ の同定式は, $\overline{\boldsymbol{P V}}_{\mathrm{in}, t}^{\mathrm{M}}$ を用いて次式で表せる.

$$
T_{t}^{l, n}=f\left(\overline{\boldsymbol{P V}}_{\mathrm{in}, t}^{\mathrm{M}}\right) \quad(l=1,2, \cdots, L ; n=1,2, \cdots, N)
$$

ここで, $f$ : 応答時定数の入力プロセス值に対する依存性を表す同定式, $L$ : 入力プロセス值の総数, $N$ : 出力プ ロセス值の総数. 得られた応答時定数を用いて, 平均化処理時間 $\Delta t$ 分の時間遅れ特性を考慮した出力プロセス値

(以後, 推定出力プロセス值)を算出する. 対象プロセスの応答を線形と見なせるように $\Delta t$ を適切に設定すれば, 出力プロセス值の応答は各入力プロセス值の $\Delta t$ 間の変化に対する応答の重㸚合わせで表現できる，そこで，時刻 $t$ における $n$ 番目の推定出力プロセス值 $P V_{\mathrm{out}, t}^{\mathrm{E}, \mathrm{t}}$ を次式で表す.

$$
P V_{\text {out }, t}^{\mathrm{E}, n}=P V_{\text {out }, t-\Delta t}^{\mathrm{E}, n}+\sum_{l=1}^{L}\left\{\left(\left.P V_{\text {out }, t}^{\mathrm{S}, n}\right|_{\overline{P V_{\mathrm{in}, t}}} ^{\mathrm{M}, l}-\left.P V_{\text {out }, t-\Delta t}^{\mathrm{S}, n}\right|_{P V_{\mathrm{in}, t-\Delta t}^{\mathrm{M}, l}}\right)\left(1-\mathrm{e}^{-\frac{\Delta t}{T_{t}^{l, n}}}\right)\right\} \quad(n=1,2, \cdots, N)
$$

ここで, 時刻 $t$ における $l$ 番目の入力プロセス值 $\overline{P V} \overline{\mathrm{in}}, t^{\mathrm{M}, l}$ に応じた定常状態での $n$ 番目の出力プロセス值 $P V_{\mathrm{out}, t}^{\mathrm{S}, n}$ は, 他 の入力プロセス值が変化しないと仮定して入出力特性モデルより算出する.

対象プロセスの性能監視を行うため，平均化処理時間ごとに算出される $\overline{\boldsymbol{P}} \overline{\mathrm{out}}, t^{\mathrm{M}}$ と $\boldsymbol{P} \boldsymbol{V}_{\mathrm{out}, t}^{\mathrm{S}}$ （動的補償を適用しな い出力プロセス值）もしくはP $\boldsymbol{V}_{\mathrm{out}, t}^{\mathrm{E}}$ （動的補償を適用寸る出力プロセス值）の対応する各成分について，次式で 示す性能監視指標 $I_{t}^{n}$ を定義する.

$$
I_{t}^{n}=\left\{\begin{array}{ll}
\frac{\overline{P V}_{\text {out }, t}^{\mathrm{M}, n}}{P V_{\text {out }, t}^{\mathrm{S}, n}} & \text { (without dynamic compensation) } \\
\frac{\overline{P V}_{\text {out }, t}^{\mathrm{M}, n}}{P V_{\mathrm{out}, t}^{\mathrm{E}, n}} & \text { (with dynamic compensation) }
\end{array} \quad(n=1,2, \cdots, N)\right.
$$

監視指標の内いずれかが正常值 (1.0) から一定時間継続して閾值を超えた場合に機器異常が生じたものと見なす. 対象プロセスの時間遅れ特性を考慮したモデルベース性能監視としては，動的シミュレーションにより対象プ ロセスの挙動を逐次算出して測定值と比較する方法も考えられる. しかし, 本論文では構築した性能監視機能を 既存の制御システムに追加実装することを念頭に置いている，本章で述べたモデルベース性能監視手法では，平 均化処理時間ごとに演算処理を行えば良いため，制御システムの演算負荷の増加を極力抑えることができる．ま 
た, 入出力モデルは各構成機器をモジュール化した上で機器の接続条件や対象プロセスの境界条件を考慮するた め, 機器の台数や構成の変更を容易に行うことができる.

\section{3. 対象プロセスとそのシミュレータ}

分散型エネルギーシステムの一例として民生用ガスエンジンコージェネレーションシステムに着目し，そのボ トミングに配置される熱利用プロセスに対して，前章で構築したモデルベース性能監視手法を適用する．本章で は対象プロセスとそのシミュレータについて述べる.

\section{$3 \cdot 1$ 対象プロセス}

対象プロセスの構成を図 2 に示す．熱源であるガスエンジン排熱から温水を介して回収した熱は水一水熱交換 器 HE の高温側に流入し, 低温側に流入する給水 (エネルギー需要量に応じて流量が変化) の加熱に利用される. 余剩熱は空冷式ラジエータ RD で放熱され, 温水は熱源に戻される. 熱源への戻り温水温度を一定に保つために, $\mathrm{HE}$ を含む温度制御ループ（図中，CL-1）と RD を含む温度制御ループ（図中，CL-2）を構築する．いずれの温 度制御ループにおいても, 調節弁には混合三方弁を用いることとし，コントローラで演算された操作信号に基づ き $\mathrm{HE}$ または RD を通過する温水とバイパス温水の流量比率を操作寸る.

温度制御ループ CL-1 における制御量は温度伝送器 TI1 で測定する調節弁 CV1 下流の温水温度である. HE 低 温側の給水流量が定格值以下の場合には，循環温水が全量 HE に流入しても HE 高温側出口温度は目標值よりも 高くなる. しかし，給水流量が定格值より多くなると HE 高温側出口温度は目標值よりも低くなるため，コント ローラ TC1 ではバイパス温水流量を増やすように操作信号を出力し, 温度伝送器 TI1 での測定温水温度を目標值 に保つ. 一方, 温度制御ループ CL-2 における制御量は温度伝送器 TI2 で測定寸る調節弁 CV 2 下流の温水温度で ある. 温度伝送器 TI2 での測定温水温度が目標值より高い場合には, RD に流入する温水流量を増やすようにコ ントローラ TC2 が操作信号を出力寸る．RD は給水負荷が無い状態でもガスエンジンが運転できるように，ガス エンジンの定格排熱回収量と同等の放熱容量を持つ必要がある.よって, 給水流量が定格值に近い場合には, 余 剩熱が少ないために RD に流入する温水流量も少なくなり, RD 出口温水温度の応答が非常に緩やかになる.

\section{$3 \cdot 2$ プロセスシミュレータ}

本論文では対象プロセスのシミュレータを構築して，任意の機器異常状態を模擬する．以後の検討では，プ ロセスシミュレータ出力を対象プロセスの測定值と見なす。これまでにガスエンジンコージェネレーション システムのシミュレーションモデルが構築されているが(15), 本論文ではこれを対象プロセスに拡張する. プ ロセスシミュレータは, 各構成機器の動的な性能特性式に加えて, それらの接続条件, および境界条件から 構成される.

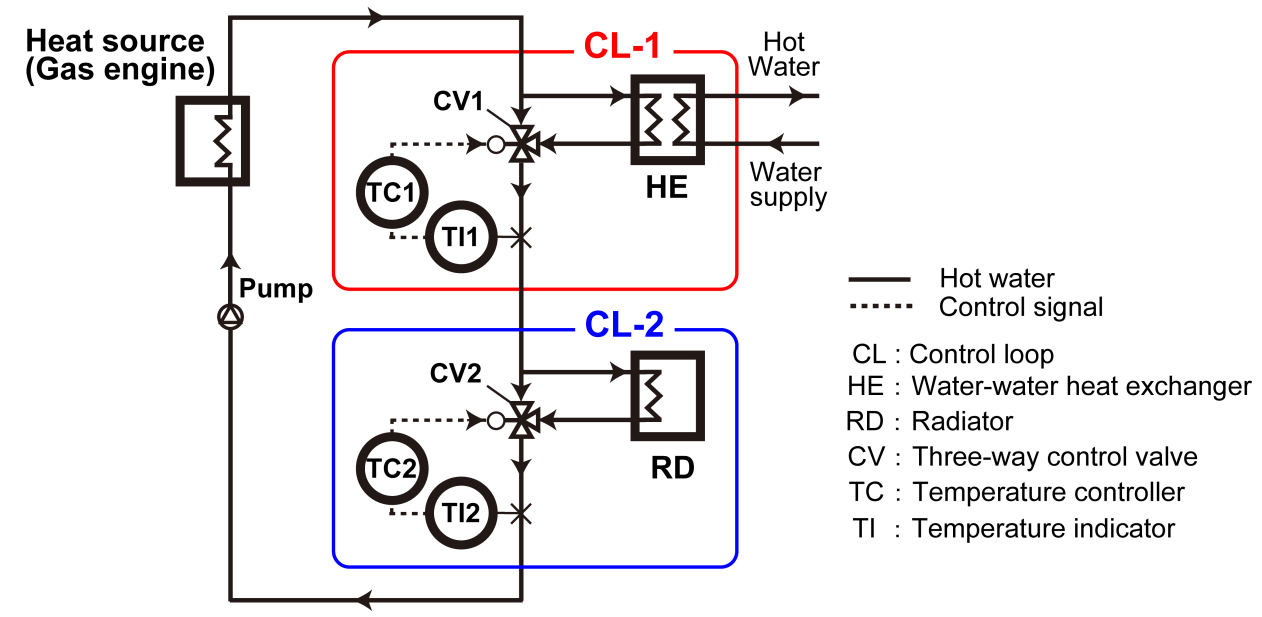

Fig. 2 Configuration of target heat utilization process 


\section{$3 \cdot 2 \cdot 1$ 機器特性の定式化}

対象プロセスの構成機器について, 基本的に温水あるいは空気の質量流量と温度を変数として採用し，以下の ように動的状態下での物質収支式および熱収支式を定式化する. 式中で使用する水と空気の物性值は PROPATH Ver.12.1 を用いて算出する.

\section{[ガスエンジン]}

ガスエンジンは集中系でモデル化する. 発電出力 $E_{\mathrm{GE}}[\mathrm{W}]$ と都市ガス消費量 $F_{\mathrm{GE}}\left[\mathrm{Nm}^{3} / \mathrm{s}\right]$ は, 発電出力設定值 $E_{\mathrm{GE}}^{\mathrm{SP}}[\mathrm{W}]$ を用いて次式の関係にあるものとし，発電出力設定值の変化に対する発電出力の応答特性を考慮する.

$$
\left.\begin{array}{l}
T_{\mathrm{GE}}^{\mathrm{E}} \frac{d E_{\mathrm{GE}}(t)}{d t}+E_{\mathrm{GE}}(t)=E_{\mathrm{GE}}^{\mathrm{SP}}(t) \\
F_{\mathrm{GE}}(t)=\frac{E_{\mathrm{GE}}^{\mathrm{SP}}(t)}{\eta_{\mathrm{GE}}^{\mathrm{E}}\left(E_{\mathrm{GE}}^{\mathrm{SP}}(t)\right) H_{\mathrm{U}}}
\end{array}\right\}
$$

ここで, $T_{\mathrm{GE}}^{\mathrm{E}}$ : 発電出力設定值の変化に対寸る発電出力の遅れを表す応答時定数 $[\mathrm{s}], \eta_{\mathrm{GE}}^{\mathrm{E}}$ : 発電効率, $H_{\mathrm{U}}$ : 都市 ガス発熱量 $\left[\mathrm{J} / \mathrm{Nm}^{3}\right]$, 下付添字 $\mathrm{GE}$ : ガスエンジン. 発電効率は部分負荷特性を考慮し, 発電出力設定值の関数と して表す. また, 回収排熱量 $Q_{\mathrm{GE}}[\mathrm{W}]$ に関する熱収支式は次式で表し, 都市ガス消費量の変化に対するガスエン ジン発熱量 $Q_{\mathrm{GE}}^{\mathrm{H}}[\mathrm{W}]$ の応答のむだ時間特性を考慮する ${ }^{(15)}$.

$$
\left.\begin{array}{l}
Q_{\mathrm{GE}}(t)=\eta_{\mathrm{GE}}^{\mathrm{Q}}\left(Q_{\mathrm{GE}}^{\mathrm{H}}(t)\right) Q_{\mathrm{GE}}^{\mathrm{H}}(t) \\
Q_{\mathrm{GE}}^{\mathrm{H}}(t)=H_{\mathrm{U}} F_{\mathrm{GE}}\left(t-\tau_{\mathrm{GE}}\right) \\
\rho_{\mathrm{GE}}^{\mathrm{W}} c_{\mathrm{GE}}^{\mathrm{W}} V_{\mathrm{GE}} \frac{d \theta_{\mathrm{GE}}^{\mathrm{W}, \text { out }}(t)}{d t}=g_{\mathrm{GE}}^{\mathrm{W}}(t) c_{\mathrm{GE}}^{\mathrm{W}}\left\{\theta_{\mathrm{GE}}^{\mathrm{W}, \text { in }}(t)-\theta_{\mathrm{GE}}^{\mathrm{W}, \text { out }}(t)\right\}+Q_{\mathrm{GE}}(t)
\end{array}\right\}
$$

ここで, $\eta_{\mathrm{GE}}^{\mathrm{Q}}$ : 排熱回収効率, $\tau_{\mathrm{GE}}$ : むだ時間 $[\mathrm{s}], \rho:$ 密度 $\left[\mathrm{kg} / \mathrm{m}^{3}\right], c:$ 比熱 $[\mathrm{J} /(\mathrm{kg} \cdot \mathrm{K})], V:$ 容積 $\left[\mathrm{m}^{3}\right], \theta:$ 温 度 $[\mathrm{K}], g$ : 質量流量 $[\mathrm{kg} / \mathrm{s}]$, 上付添字 $\mathrm{W}$ : 水に関する物理量, in : 入口, out : 出口. 排熱回収効率は部分負 荷特性を考慮し,ガスエンジン発熱量の関数として表す.外気への放熱は排気熱 $\left(=H_{\mathrm{U}} F_{\mathrm{GE}}(t)-E_{\mathrm{GE}}(t)-Q_{\mathrm{GE}}(t)\right)$ に含まれるものとする. 水の密度と比熱は出入口温水温度の相加平均より算出する. さらに, 式 (6) より, 回収 排熱量の変化に対する出口温水温度の遅れを表す応答時定数 $T_{\mathrm{GE}}^{\mathrm{Q}}[\mathrm{s}]$ を次式で定義する ${ }^{(15)}$.

$$
T_{\mathrm{GE}}^{\mathrm{Q}}=\frac{\rho_{\mathrm{GE}}^{\mathrm{W}} V_{\mathrm{GE}}}{g_{\mathrm{GE}}^{\mathrm{W}}(t)}
$$

\section{[水一水熱交換器 $(\mathrm{HE})$ ]}

HE に関しては，プレート式熱交換器を集中系でモデル化し，高温側，低温側それぞれの熱収支式を次式のよ うに定式化する。

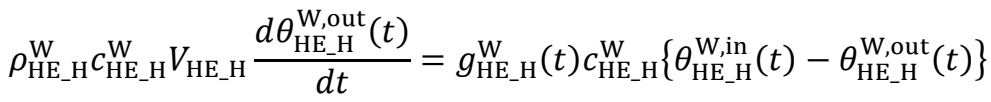

$$
\begin{aligned}
& \left.-K_{\mathrm{HE}} A_{\mathrm{HE}} \Delta \theta_{\mathrm{HE}}^{\mathrm{L}}(t)-K_{\mathrm{HE}_{-} \mathrm{H}}^{1} A_{\mathrm{HE}}^{1}\left\{\frac{\theta_{\mathrm{HE} \_\mathrm{H}}^{\mathrm{W}, \mathrm{in}}(t)+\theta_{\mathrm{HE} \_\mathrm{H}}^{\mathrm{W}, \text { out }}(t)}{2}-\theta^{\mathrm{A}}(t)\right\}\right\} \\
& \rho_{\mathrm{HE} \_\mathrm{L}}^{\mathrm{W}} c_{\mathrm{HE} \_\mathrm{L}}^{\mathrm{W}} V_{\mathrm{HE} \_\mathrm{L}} \frac{d \theta_{\mathrm{HE} \_\mathrm{L}}^{\mathrm{W}, o u t}(t)}{d t}=g_{\mathrm{HE} \_\mathrm{L}}^{\mathrm{W}}(t) c_{\mathrm{HE} \_\mathrm{L}}^{\mathrm{W}}\left\{\theta_{\mathrm{HE} \_\mathrm{L}}^{\mathrm{W}, \text { in }}(t)-\theta_{\mathrm{HE} \_\mathrm{L}}^{\mathrm{W}, \text { out }}(t)\right\} \\
& \left.+K_{\mathrm{HE}} A_{\mathrm{HE}} \Delta \theta_{\mathrm{HE}}^{\mathrm{L}}(t)-K_{\mathrm{HE} \_\mathrm{L}}^{1} A_{\mathrm{HE}}^{1}\left\{\frac{\theta_{\mathrm{HE} \_\mathrm{L}}^{\mathrm{W}, \mathrm{in}}(t)+\theta_{\mathrm{HE} \_\mathrm{L}}^{\mathrm{W}, \text { out }}(t)}{2}-\theta^{\mathrm{A}}(t)\right\}\right\}
\end{aligned}
$$


ここで, $K$ : 熱通過率 $\left[\mathrm{W} /\left(\mathrm{m}^{2} \cdot \mathrm{K}\right)\right], A$ : 伝熱面積 $\left[\mathrm{m}^{2}\right], \Delta \theta^{\mathrm{L}}$ : 対数平均温度差 $[\mathrm{K}]$, 上付添字 $\mathrm{A}:$ 空気に関する 物理量, $\mathrm{l}$ : 放熱, 下付添字 HE : 水一水熱交換器, $\mathrm{H}$ : 高温側, $\mathrm{L}$ : 低温側. 水の密度と比熱は高温側, 低温側と もに出入口温水温度の相加平均より算出する.

また，式（8）において，熱通過率 $K_{\mathrm{HE}}$ は次式で算出する ${ }^{(16)}$.

$$
K_{\mathrm{HE}}=\left[\frac{1}{\alpha_{\mathrm{HE} \_\mathrm{H}}}+\frac{t_{\mathrm{P}}}{\lambda_{\mathrm{P}}}+\frac{1}{\alpha_{\mathrm{HE} \_\mathrm{L}}}\right]^{-1}
$$

ここで, $\alpha$ : 熱伝達率 $\left[\mathrm{W} /\left(\mathrm{m}^{2} \cdot \mathrm{K}\right)\right], t$ : 厚さ $[\mathrm{m}], \lambda$ : 熱伝導率 $[\mathrm{W} /(\mathrm{m} \cdot \mathrm{K})]$, 下付添字 $\mathrm{P}:$ プレート. 式 (9)に おける熱伝達率 $\alpha_{\mathrm{HE}}$ は高温側, 低温側ともに次式より算出する ${ }^{(16)}$.

$$
\frac{\alpha_{\mathrm{HE}} D_{\mathrm{HEe}}}{\lambda_{\mathrm{HE}}^{\mathrm{W}}}=C_{1}\left(\frac{D_{\mathrm{HEe}} G_{\mathrm{HE}}^{\mathrm{W}}}{\mu_{\mathrm{HE}}^{\mathrm{W}}}\right)^{C_{2}}\left(\frac{c_{\mathrm{HE}}^{\mathrm{W}} \mu_{\mathrm{HE}}^{\mathrm{W}}}{\lambda_{\mathrm{HE}}^{\mathrm{W}}}\right)^{\frac{1}{3}}
$$

ここで, $D_{\mathrm{HEe}}$ : 相当直径 $\left(\right.$ プレート間隔の 2 倍） $[\mathrm{m}], G$ : 質量速度 $\left[\mathrm{kg} /\left(\mathrm{m}^{2} \cdot \mathrm{s}\right)\right], \mu$ : 粘性係数 $[\mathrm{Pa} \cdot \mathrm{s}], C_{1}, C_{2}$ ： 定数（本論文では， $C_{1}=0.165, C_{2}=0.68$ ). 水の熱伝導率，粘性係数，および比熱は高温側，低温側ともに出 入口温水温度の相加平均より算出する. また, 質量速度は, プレート幅 $b_{\mathrm{HE}}[\mathrm{m}]$, プレート枚数 $N_{\mathrm{HE}}$, およびプレ 一ト間隔 $\delta_{\mathrm{HE}}[\mathrm{m}]$ 用いて次式より算出する.

$$
G_{\mathrm{HE}}^{\mathrm{W}}=\frac{g_{\mathrm{HE}}^{\mathrm{W}}}{b_{\mathrm{HE}} N_{\mathrm{HE}} \delta_{\mathrm{HE}}}
$$

式（9）〜（11）より，熱通過率 $K_{\mathrm{HE}}$ は高温側および低温側の流量と温度の変化を考慮していることがわかる.

\section{[空冷式ラジェータ (RD) ]}

出口温水温度の応答が緩やかになりうる $\mathrm{RD}$ はフィン・チューブ式熱交換器（直交流型）を分布系で定式化す る. 比熱が小さく, 流量の多い空気の温度変化は温水に比べて非常に速いため, 時間遅れは温水のみ考慮する. また，各伝熱管に均等に温水流量が配分され，いずれの伝熱管内の温度分布も等しいと仮定する.さらに，熱通 過率 $K_{\mathrm{RD}}$ を伝熱管長手方向に一定とみなすと, 温水の流れ方向に対して $I$ 個のコントロールボリュームに分割し た時の各コントロールボリュームにおける温水側および空気側の熱収支式は次式で表せる.

$$
\begin{array}{r}
\rho_{\mathrm{RD}}^{\mathrm{W}} c_{\mathrm{RD}}^{\mathrm{W}} S_{\mathrm{RD}} \Delta x_{\mathrm{RD}} \frac{d \theta_{\mathrm{RD}}^{\mathrm{W}, i}(t)}{d t}=g_{\mathrm{RD}}^{\mathrm{W}}(t) c_{\mathrm{RD}}^{\mathrm{W}}\left\{\theta_{\mathrm{RD}}^{\mathrm{W}, i-1}(t)-\theta_{\mathrm{RD}}^{\mathrm{W}, i}(t)\right\}-K_{\mathrm{RD}} \frac{A_{\mathrm{RD}}}{I}\left\{\theta_{\mathrm{RD}}^{\mathrm{W}, i-1}(t)-\theta_{\mathrm{RD}}^{\mathrm{A}, \mathrm{in}}(t)\right\} \\
g_{\mathrm{RD}}^{\mathrm{A}}(t) c_{\mathrm{RD}}^{\mathrm{A}}\left\{\theta_{\mathrm{RD}}^{\mathrm{A}, \mathrm{in}}(t)-\theta_{\mathrm{RD}}^{\mathrm{A}, \text { out }}(t)\right\}+K_{\mathrm{RD}} \frac{A_{\mathrm{RD}}}{I}\left\{\theta_{\mathrm{RD}}^{\mathrm{W}, i-1}(t)-\theta_{\mathrm{RD}}^{\mathrm{A}, \mathrm{in}}(t)\right\}=0
\end{array} \quad \begin{array}{r}
(i=1,2, \cdots, I)
\end{array}
$$

ここで, $S$ : 伝熱管総断面積 $\left[\mathrm{m}^{2}\right], \Delta x$ : コントロールボリューム長さ $[\mathrm{m}]$, 下付添字 $\mathrm{RD}$ : 空冷式ラジエータ. 水の密度と比熱は出入口温水温度の相加平均より, 空気の比熱は出入口空気温度の相加平均より算出する.

また，式（12）において，熱通過率 $K_{\mathrm{RD}}$ は次式より算出する ${ }^{(17)}$.

$$
K_{\mathrm{RD}}=\frac{1}{A_{\mathrm{RD}}}\left[\frac{1}{\alpha_{\mathrm{RD}}^{\mathrm{A}}\left(A_{\mathrm{T}}^{\mathrm{A}}+\phi_{\mathrm{F}} A_{\mathrm{F}}\right)}+\frac{1}{\alpha_{\mathrm{RD}}^{\mathrm{W}} \mathrm{A}_{\mathrm{T}}^{\mathrm{W}}}\right]^{-1}
$$

ここで, $A_{\mathrm{RD}}$ : フィン側総伝熱面積 $\left(=A_{\mathrm{T}}^{\mathrm{A}}+A_{\mathrm{F}}\right) \quad\left[\mathrm{m}^{2}\right], A_{\mathrm{T}}$ : 伝熱管表面積 $\left[\mathrm{m}^{2}\right], A_{\mathrm{F}}$ : フィン伝熱面積 $\left[\mathrm{m}^{2}\right], \phi_{\mathrm{F}}$ : フィン効率. 式（13）における空気側（フィン側）の熱伝達率 $\alpha_{\mathrm{RD}}^{\mathrm{A}}$ は藤掛の式 ${ }^{(17)}$ より算出する. 


$$
\frac{\alpha_{\mathrm{RD}}^{\mathrm{A}} D_{\mathrm{F}}}{\lambda_{\mathrm{RD}}^{\mathrm{A}}}=2 R_{\mathrm{F}}\left\{1.1+0.55\left(\operatorname{Re}_{\mathrm{RD}}^{\mathrm{A}} \operatorname{Pr}_{\mathrm{RD}}^{\mathrm{A}} \frac{D_{\mathrm{F}}}{L_{\mathrm{F}}} \frac{1}{4 R_{\mathrm{F}}^{2}}\right)^{0.55}\right\}
$$

ここで， $D_{\mathrm{F}}$ はフィン代表長さ $[\mathrm{m}] ， R_{\mathrm{F}}$ はフィン寸法より決定される定数で，フィン幅 $L_{\mathrm{F}}[\mathrm{m}]$ に基づくそれぞれの 算出方法は文献(17)を参照のこと. 空気の熱伝導率, プラントル数は出入口空気温度の相加平均より, また, レ イノルズ数は流入空気平均流速, フィン代表長さ, および出入口空気温度の相加平均よりそれぞれ算出する. ま た，式（13）においてフィン効率 $\phi_{\mathrm{F}}$ は藤掛の式(17)より算出する.

$$
\phi_{\mathrm{F}}=\frac{\tanh \left(\frac{H_{\mathrm{F}}}{2} \sqrt{Z_{\mathrm{F}} \frac{2 \alpha_{\mathrm{RD}}^{\mathrm{A}}}{\lambda_{\mathrm{F}} t_{\mathrm{F}}}}\right)}{\frac{H_{\mathrm{F}}}{2} \sqrt{Z_{\mathrm{F}} \frac{2 \alpha_{\mathrm{RD}}^{\mathrm{A}}}{\lambda_{\mathrm{F}} t_{\mathrm{F}}}}}
$$

ここで, $H_{\mathrm{F}}$ : フィン高さ $[\mathrm{m}], Z_{\mathrm{F}}$ : フィン構造より決定される定数 (算出方法は文献(17)を参照), 下付添字 $\mathrm{F}$ : フィン．また，式（13）における温水側（管内側）の熱伝達率 $\alpha_{\mathrm{RD}}^{\mathrm{W}}$ の算出には Dittus-Boelter の式(18)を用いる.

$$
\frac{\alpha_{\mathrm{RD}}^{\mathrm{W}} D_{\mathrm{T}}}{\lambda_{\mathrm{RD}}^{\mathrm{W}}}=0.023 \operatorname{Re}_{\mathrm{RD}}^{\mathrm{W}}{ }^{0.8} \operatorname{Pr}_{\mathrm{RD}}^{\mathrm{W}}
$$

ここで, $D_{\mathrm{T}}$ : 伝熱管内径 $[\mathrm{m}]$. 水の熱伝導率，プラントル数は出入口温水温度の相加平均より，レイノルズ数は 伝熱管内平均流速，伝熱管内径，および出入口温水温度の相加平均よりそれぞれ算出する.

式（13）～（16）より，熱通過率 $K_{\mathrm{RD}}$ は温水および空気の流量と温度の変化を考慮していることがわかる.

\section{[調節弁]}

調節弁については混合三方弁を集中系で定式化する. 図 2 に示すように，2 方向（流入口 1 および 2）より温 水が流入し，混合した温水が流出する場合の物質収支式は次式で表せる.

$$
\left.\begin{array}{l}
g_{\mathrm{CV}}^{\mathrm{W}, \text { in } 1}(t)+g_{\mathrm{CV}}^{\mathrm{W} \text {,in2 }}(t)=g_{\mathrm{CV}}^{\mathrm{W}, \text { out }}(t) \\
g_{\mathrm{CV}}^{\mathrm{W}, \text { in } 1}(t)=\varepsilon_{\mathrm{CV}}(t) g_{\mathrm{CV}}^{\mathrm{W} \text {,out }}(t) \\
g_{\mathrm{CV}}^{\mathrm{W} \text {,in2 }}(t)=\left\{1-\varepsilon_{\mathrm{CV}}(t)\right\} g_{\mathrm{CV}}^{\mathrm{W}, \text { out }}(t)
\end{array}\right\}
$$

ここで, $\varepsilon$ : 弁開度, 上付添字 in $1:$ 流入口 1, in2 : 流入口 2, 下付添字 $\mathrm{CV}:$ 調節弁. 2 方向より流入した温水 が完全に混合すると見なした場合の熱収支式は次式で表せる.

$$
\varepsilon_{\mathrm{CV}}(t) g_{\mathrm{CV}}^{\mathrm{W} \text {,out }}(t) c_{\mathrm{CV}}^{\mathrm{W}} \theta_{\mathrm{CV}}^{\mathrm{W} \text {,in1 }}(t)+\left\{1-\varepsilon_{\mathrm{CV}}(t)\right\} g_{\mathrm{CV}}^{\mathrm{W}, \text { out }}(t) c_{\mathrm{CV}}^{\mathrm{W}} \theta_{\mathrm{CV}}^{\mathrm{W} \text {,in2 }}(t)=g_{\mathrm{CV}}^{\mathrm{W}, \text { out }}(t) c_{\mathrm{CV}}^{\mathrm{W}} \theta_{\mathrm{CV}}^{\mathrm{W} \text {,out }}(t)
$$

さらに，定式化は省略するが，操作信号に対する弁開度の応答特性を一次遅れ系で表す.

\section{[配管]}

配管長が比較的短いことから配管は集中系でモデル化する．放熱損失を考慮した熱収支式は次式で表せる.

$$
\rho_{\mathrm{PP}}^{\mathrm{W}} c_{\mathrm{PP}}^{\mathrm{W}} V_{\mathrm{PP}} \frac{d \theta_{\mathrm{PP}}^{\mathrm{W}, \text { out }}(t)}{d t}=g_{\mathrm{PP}}^{\mathrm{W}}(t) c_{\mathrm{PP}}^{\mathrm{W}}\left\{\theta_{\mathrm{PP}}^{\mathrm{W}, \text { in }}(t)-\theta_{\mathrm{PP}}^{\mathrm{W}, \text { out }}(t)\right\}-K_{\mathrm{PP}}^{\mathrm{l}} A_{\mathrm{PP}}\left\{\frac{\theta_{\mathrm{PP}}^{\mathrm{W}, \text { in }}(t)+\theta_{\mathrm{PP}}^{\mathrm{W} \text {,out }}(t)}{2}-\theta^{\mathrm{A}}(t)\right\}
$$

ここで，下付添字 PP : 配管. 


\section{[その他の機器]}

温度伝送器については，定式化は省略するが，調節弁下流での測定温水温度に対する温度信号の応答特性 を一次遅れ系で表す．また, 調節弁下流の温水温度を一定に保持するためのコントローラには, ディジタル 演算式のフィードバック制御（PI 動作）を採用する. 操作信号 $u_{\mathrm{TI}}$ は制御間隔 $\Delta t_{\mathrm{C}}[\mathrm{s}]$ ごとにディジタル演算 を行うための整数変数 $m, k$ を用いて次式で表される.

$$
\left.\begin{array}{l}
e\left(m \Delta t_{\mathrm{C}}\right)=\theta_{\mathrm{TI}}^{\mathrm{W}, \mathrm{SP}}(t)-\theta_{\mathrm{TI}}^{\mathrm{W}}\left(m \Delta t_{\mathrm{C}}\right) \\
u_{\mathrm{TI}}\left(m \Delta t_{\mathrm{C}}\right)=K_{\mathrm{P}}\left[e\left(m \Delta t_{\mathrm{C}}\right)+\frac{\Delta t_{\mathrm{C}}}{T_{\mathrm{I}}} \sum_{k=0}^{m} e\left(k \Delta t_{\mathrm{C}}\right)\right]
\end{array}\right\} \quad(m=1,2, \cdots)
$$

ここで, $e$ : 偏差 $[\mathrm{K}], \theta_{\mathrm{TI}}^{\mathrm{W}}:$ 温度信号, $K_{\mathrm{P}}$ : 比例ゲイン $[1 / \mathrm{K}], T_{\mathrm{I}}$ : 積分時間 $[\mathrm{s}]$, 上付添字 $\mathrm{SP}:$ 設定值.

\section{$3 \cdot 2 \cdot 2$ 接続条件および境界条件}

各機器をモジュールと見なし，その接続点において対応する変数の值を等しくする接続条件を考慮する.また， 対象プロセスの境界点において給水や外気温などの境界条件を考慮する.

\section{$3 \cdot 2 \cdot 3$ 数值解法}

以上に定式化したモデルには静特性を表す代数方程式と動特性を表す微分方程式が混在し, 次式のような 非線形連立混合微分代数方程式で表すことができる.

$$
\left.\begin{array}{l}
\boldsymbol{f}_{\mathrm{SIM}}\left(\boldsymbol{x}(t), \boldsymbol{x}^{\prime}(t), \boldsymbol{y}(t), t\right)=\mathbf{0} \\
\boldsymbol{x}\left(t_{0}\right)=\boldsymbol{x}_{\mathbf{0}}
\end{array}\right\}
$$

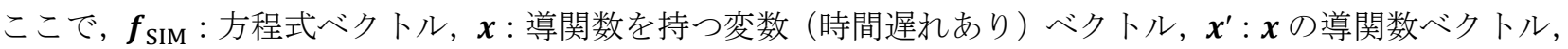
$\boldsymbol{y}$ : 導関数を持たない変数 (時間遅れなし) べクトル, $t$ : 時間, $t_{0}:$ 初期時刻, $\boldsymbol{x}_{\mathbf{0}}: \boldsymbol{x}$ の初期值ベクトル.こ こでは，オイラー法とニュートン-ラフソン法を組み合わせて，この連立方程式を数值的に解く.

\section{$3 \cdot 3$ 計算条件}

本論文で設定する計算条件を示す，微分方程式を解くための計算ステップは 0.1 秒とする.

\section{$3 \cdot 3 \cdot 1$ 機器の主要諸元}

対象とする定格発電出力 $25 \mathrm{~kW}$ のガスエンジンコージェネレーションシステム ${ }^{(19)}$ の主要諸元を表 1 に示す. HE はSUS316 製，RD はアルミニウム製でフィン間流路形状は三角形とし，ガスエンジン定格温水出力と同容量 の交換熱量，放熱量をそれぞれ持つものとする. ガスエンジン，HE，RDをそれぞれ接続する配管（呼び径 40A) の長さはいずれも $1.3 \mathrm{~m}$ とする. 調節弁, 温度伝送器の応答時定数はそれぞれ 1 秒, 2 秒とする.

\section{$3 \cdot 3 \cdot 2$ 制御条件}

各コントローラの調整值を表 2 に示す.いずれの温水温度目標值も $79^{\circ} \mathrm{C} と し$, ディジタル制御演算のための制 御周期 $\Delta t$ は 1 秒とする.

\section{$3 \cdot 3 \cdot 3$ 境界条件}

境界条件として，ガスエンジン発電出力設定值，給水流量・温度，および外気温を決定する必要がある，民生用 ガスエンジンコージェネレーションシステムでは，極力，定格出力で運転することが高い省エネルギー効果を得 るために重要であることから ${ }^{(20)}$, ガスエンジンは定格出力一定で運転するものとし, 対象プロセスにとっての負 荷である給水流量を変化させる．給水流量は対象プロセス内の循環温水が全量 RD をバイパス寸る $0.212 \mathrm{~kg} / \mathrm{s}$ 定格值として正規化して表す．給水温度，外気温は中間期を想定してそれぞれ $17^{\circ} \mathrm{C} ， 16^{\circ} \mathrm{C}$ する。 
Table 1 Specifications of target gas engine cogeneration system

\begin{tabular}{|c|c|c|c|c|}
\hline Components & \multicolumn{3}{|l|}{ Specifications } & Values \\
\hline \multirow{8}{*}{ Gas engine } & Rated electric power output & & $\mathrm{kW}$ & 25.0 \\
\hline & Rated hot water output & & $\mathrm{kW}$ & 39.7 \\
\hline & Rated generating efficiency & & $\%$ & 33.1 \\
\hline & Rated heat recovery efficiency & & $\%$ & 52.4 \\
\hline & Time constant for electric power output & $T_{\mathrm{GE}}^{\mathrm{E}}$ & $\mathrm{s}$ & 1.0 \\
\hline & Time constant for hot water output & $T_{\mathrm{GE}}^{\mathrm{Q}}$ & $\mathrm{s}$ & 18.0 \\
\hline & Dead time for input heating rate & $\tau_{\mathrm{GE}}$ & $\mathrm{s}$ & 10.0 \\
\hline & Flow rate of circulating hot water & $g_{\mathrm{GE}}^{\mathrm{W}}$ & $\mathrm{kg} / \mathrm{s}$ & 1.72 \\
\hline \multirow{4}{*}{$\begin{array}{l}\text { Water-water } \\
\text { heat exchanger } \\
(\mathrm{HE})\end{array}$} & Heat transfer area & $A_{\mathrm{HE}}$ & $\mathrm{m}^{2}$ & 0.6 \\
\hline & Outside surface area & $A_{\mathrm{HE}}^{1}$ & $\mathrm{~m}^{2}$ & $0.25 \times 10^{-2}$ \\
\hline & Volume & $V_{\mathrm{HE}}$ & $\mathrm{m}^{3}$ & $1.83 \times 10^{-3}$ \\
\hline & Overall heat transfer coefficient for heat loss & $K_{\mathrm{HE}}^{1}$ & $\mathrm{~W} /\left(\mathrm{m}^{2} \cdot \mathrm{K}\right)$ & 0.8 \\
\hline \multirow{6}{*}{$\begin{array}{l}\text { Radiator } \\
\text { (RD) }\end{array}$} & Overall heat transfer area & $A_{\mathrm{RD}}$ & $\mathrm{m}^{2}$ & 8.94 \\
\hline & Water-side surface area of tube & $A_{\mathrm{T}}^{\mathrm{W}}$ & $\mathrm{m}^{2}$ & 1.64 \\
\hline & Air-side surface area of tube & $A_{\mathrm{T}}^{\mathrm{A}}$ & $\mathrm{m}^{2}$ & 1.68 \\
\hline & Surface area of fin & $A_{\mathrm{F}}$ & $\mathrm{m}^{2}$ & 7.26 \\
\hline & Total cross-section area of tube & $S_{\mathrm{RD}}$ & $\mathrm{m}^{2}$ & $2.88 \times 10^{-3}$ \\
\hline & Total number of control volume & $I$ & & 100 \\
\hline Pipe & Overall heat transfer coefficient for heat loss & $K_{\mathrm{PP}}^{1}$ & $\mathrm{~W} /\left(\mathrm{m}^{2} \cdot \mathrm{K}\right)$ & 0.8 \\
\hline
\end{tabular}

Table 2 Control parameters

\begin{tabular}{|lll|l|l|}
\hline Control parameters & & & TC1 & TC2 \\
\hline Proportional gain & $K_{\mathrm{P}}$ & $1 / \mathrm{K}$ & 0.08 & 0.04 \\
\hline Integral time & $T_{\mathrm{I}}$ & $\mathrm{s}$ & 10 & 5 \\
\hline
\end{tabular}

\section{4. 性能監視システムの構築}

ここでは，2 章に述べた動的補償を用いたモデルベース性能監視手法を対象プロセスに適用する.

\section{$4 \cdot 1$ 入出カモデルの構築}

入出力モデルは，対象プロセスの構成機器に関する定常特性式，接続条件，制御条件，および境界条件より構 成される.

\section{4・1・1 入・出カプロセス值}

対象プロセスの運転条件を決定する入力プロセス值として, 給水流量・温度, ガスエンジン発電出力設定值, 外気温に着目する。また，これに応じて決定される出力プロセス值として，各温度制御ループにおける温度伝送 器での測定温水温度と調節弁の操作信号，および HE と RD の出入口温水温度差に着目する.

\section{$4 \cdot 1 \cdot 2$ 機器特性の定式化}

構成機器に関しては，ガスエンジン，HE，RD，2 基の調節弁，および各機器を接続する配管の定常特性を定式 化する. これは基本的に前章で述べたプロセスシミュレータにおける性能特性式の時間微分項を除いたものに相 当する. RD に関しては, 集中系と分布系で定常特性にほとんど違いが見られないことから ${ }^{(21)}$, 演算負荷の小さ な集中系で次式のように定式化する. 


$$
\left.\begin{array}{l}
g_{\mathrm{RD}}^{\mathrm{W}}(t) c_{\mathrm{RD}}^{\mathrm{W}}\left\{\theta_{\mathrm{RD}}^{\mathrm{W}, \mathrm{in}}(t)-\theta_{\mathrm{RD}}^{\mathrm{W}, \text { out }}(t)\right\}-K_{\mathrm{RD}} A_{\mathrm{RD}} \Delta \theta_{\mathrm{RD}}^{\mathrm{L}}(t)=0 \\
g_{\mathrm{RD}}^{\mathrm{A}}(t) c_{\mathrm{RD}}^{\mathrm{A}}\left\{\theta_{\mathrm{RD}}^{\mathrm{A}, \mathrm{in}}(t)-\theta_{\mathrm{RD}}^{\mathrm{A}, \text { out }}(t)\right\}+K_{\mathrm{RD}} A_{\mathrm{RD}} \Delta \theta_{\mathrm{RD}}^{\mathrm{L}}(t)=0
\end{array}\right\}
$$

熱通過率 $K_{\mathrm{RD}}$ はプロセスシミュレータと同様に算出し, 水の比熱は出入口温水温度の相加平均より算出する.

\section{$4 \cdot 1 \cdot 3$ 制御条件}

コントローラの定常特性を定式化する代わりに, 制御量（温度伝送器での測定温水温度）を目標值に一致させ る制御条件を考慮する.

\section{$4 \cdot 1 \cdot 4$ 接続条件および境界条件}

各機器をモジュールと見なし，その接続点において対応する変数の值を等しくする接続条件を考慮する. さら に，対象プロセスの境界点において境界条件を考慮する. 前述の 4 つの入力プロセス值が境界条件に相当する.

\section{$4 \cdot 1 \cdot 5$ 数值解法}

構成機器の定常特性式, 接続条件, 制御条件, および境界条件を考慮すると，入出力モデルは非線形連立代数 方程式に帰着する. これをニュートン-ラフソン法を用いて数值的に解くことで, 入力プロセス值に応じた定常状 態での出力プロセス值を算出する.

\section{$4 \cdot 2$ 動的補償の構築}

対象プロセスの 4 つの入力プロセス值の内, 給水温度および外気温の変化は給水流量の変化に比べて非常に緩 やかなこと，また，熱源であるガスエンジンは定格出力一定で運転を行うことから，本論文では入力プロセス值 として給水流量のみに着目する．給水流量は定格值以下で変動するものとし，温度制御ループ CL-1 の制御動作 が行われない運転条件を対象とする．給水流量が定格值以下であっても，ガスエンジンの発電出力が低下した場 合にはガスエンジンの出口温水温度が低下し, 温度制御ループ CL-1 で制御動作が行われうる. しかし, 本論文 ではガスエンジンの発電出力を定格值で一定とするため, 常に温度制御ループCL-2 のみが動作することになる. また，時間応答が緩やかになりうる出力プロセス值として， RD 出入口温水温度差に動的補償を適用する. 他の 出力プロセス值に関しては，時間応答が早いために動的補償の導入効果が見られなかったことを確認している.

動的補償を構築するため, 給水流量变化に対する $\mathrm{RD}$ 出入口温水温度差の応答時定数を周波数特性より算出す る. 図 2 より, 温度制御ループ CL-1 の制御動作が行われない場合には, RD 入口温水温度は給水流量变化に伴う $\mathrm{HE}$ 高温側出口の温水温度変化の影響を配管を介して受けることがわかる. また, RD 出口温水温度は入口温水温 度の変化だけでなく, ガスエンジンへの戻り温水温度を一定に保つための温度制御ループ CL-2 の制御動作の影 響も受ける. そこで, 平衡点からの微小変化分にラプラス変換を施すことで各機器の伝達関数を導出し，これよ り, 給水流量 $g_{\mathrm{S}}$ の変化に対する $\mathrm{RD}$ 出入口温水温度差の応答を表す伝達関数を導出する.

まず， HE に関しては， $g_{\mathrm{S}}(t)=g_{\mathrm{HE} \_\mathrm{L}}^{\mathrm{W}}(t)$ の境界条件を考慮して, 次式で定義する給水流量变化に対する高温側 出口温水温度の応答を表す伝達関数 $G_{\mathrm{HE}}$ を, 式 (8) より導出する.

$$
\theta_{\mathrm{HE} \_\mathrm{H}}^{\mathrm{W}, \mathrm{out}}(s)=G_{\mathrm{HE}}(s) g_{\mathrm{S}}(s)
$$

配管に関しては, $\theta_{\mathrm{HE} \_\mathrm{H}}^{\mathrm{W}, \mathrm{H}}(t)=\theta_{\mathrm{PP}}^{\mathrm{W}, \mathrm{in}}(t)$, および $\theta_{\mathrm{RD}}^{\mathrm{W}, \mathrm{in}}(t)=\theta_{\mathrm{PP}}^{\mathrm{W}, \text { out }}(t)$ の接続条件を考慮し, 次式で定義する入口温 水温度 (HE 高温側出口温水温度) 変化に対する出口温水温度 (RD 入口温水温度) の応答を表す伝達関数 $G_{\mathrm{PP}}$ を, 式(19)より導出する.

$$
\theta_{\mathrm{RD}}^{\mathrm{W}, \text { in }}(s)=G_{\mathrm{PP}}(s) \theta_{\mathrm{HE} \_\mathrm{H}}^{\mathrm{W}, \mathrm{out}}(s)
$$

$\mathrm{RD}$ に関しては, $\mathrm{RD}$ 出口温水温度が $\mathrm{RD}$ 入口温水温度と $\mathrm{RD}$ 流入温水流量の変化の影響を受けるため, 式（22）

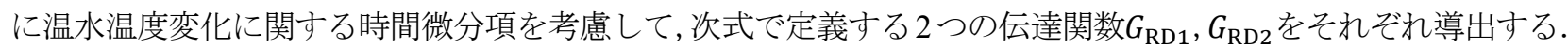




$$
\theta_{\mathrm{RD}}^{\mathrm{W}, \text { out }}(s)=G_{\mathrm{RD} 1}(s) \theta_{\mathrm{RD}}^{\mathrm{W}, \mathrm{in}}(s)+G_{\mathrm{RD} 2}(s) g_{\mathrm{RD}}^{\mathrm{W}}(s)
$$

ここで, $G_{\mathrm{RD} 1}: \mathrm{RD}$ 入口温水温度変化に対する $\mathrm{RD}$ 出口温水温度の応答を表す伝達関数, $G_{\mathrm{RD} 2}: \mathrm{RD}$ 流入温水流量 変化に対する $\mathrm{RD}$ 出口温水温度の応答を表す伝達関数. 調節弁 $\mathrm{CV} 2$ に関しては, $g_{\mathrm{CV}}^{\mathrm{W}, \mathrm{in} 2}(t)=g_{\mathrm{RD}}^{\mathrm{W}}(t)$ の接続条件, および出口温水流量 $g_{\mathrm{CV}}^{\mathrm{W}, \text { out }}$ がプロセス循環流量 $g_{\mathrm{GE}}^{\mathrm{W}}$ に等しいことを考慮して, 式 (17) より次式の入出力関係を得 る.

$$
g_{\mathrm{RD}}^{\mathrm{W}}(s)=-g_{\mathrm{GE}}^{\mathrm{W}} \varepsilon_{\mathrm{CV} 2}(s)
$$

また, $\theta_{\mathrm{CV} 2}^{\mathrm{W} \text {,in1 }}(t)=\theta_{\mathrm{RD}}^{\mathrm{W}, \mathrm{in}}(t), \theta_{\mathrm{CV} 2}^{\mathrm{W}, \text { in2 }}(t)=\theta_{\mathrm{RD}}^{\mathrm{W}, \text { out }}(t)$ の接続条件を考慮して, 式 (18) より次式の入出力関係を得る.

$$
\theta_{\mathrm{CV} 2}^{\mathrm{W}, \text { out }}(s)=D_{\mathrm{RD}}^{\mathrm{DT}} \varepsilon_{\mathrm{CV} 2}(s)+\varepsilon_{\mathrm{CV} 2}^{0} \theta_{\mathrm{RD}}^{\mathrm{W}, \text { in }}(s)+\left(1-\varepsilon_{\mathrm{CV} 2}^{0}\right) \theta_{\mathrm{RD}}^{\mathrm{W}, \text { out }}(s)
$$

ここで, $D_{\mathrm{RD}}^{\mathrm{DT}}$ : 平衡点における $\mathrm{RD}$ 出入口温水温度差 $\left(=\theta_{\mathrm{RD}}^{\mathrm{W}, \mathrm{in} \_0}-\theta_{\mathrm{RD}}^{\mathrm{W}, \mathrm{out} \_0}\right)$, 上付添字 0 : 平衡点. さらに, 次 式で定義する操作信号の変化に対する弁開度の応答を表す伝達関数 $G_{\mathrm{CV} 2}$ （一次遅れ系）を導出する.

$$
\varepsilon_{\mathrm{CV} 2}(s)=G_{\mathrm{CV} 2}(s) u_{\mathrm{CV} 2}(s)
$$

温度伝送器 TI2 に関しては, 次式で定義する測定温水温度（調節弁 CV2 下流の温水温度）の変化に対する温度 信号の応答を表す伝達関数 $G_{\mathrm{T} 12}$ （一次遅れ系）を導出する.

$$
\theta_{\mathrm{TI} 2}^{\mathrm{W}}(s)=G_{\mathrm{T} 12}(s) \theta_{\mathrm{CV} 2}^{\mathrm{W}, \text { out }}(s)
$$

コントローラに関しては, 連続系の PI 動作と見なし, 温水温度設定值が一定であることから, 次式を得る.

$$
\left.\begin{array}{l}
e_{\mathrm{TC} 2}(s)=-\theta_{\mathrm{T} 12}^{\mathrm{W}}(s) \\
u_{\mathrm{CV} 2}(s)=G_{\mathrm{TC} 2}(s) e_{\mathrm{TC} 2}(s)
\end{array}\right\}
$$

ここで, $G_{\mathrm{TC} 2}$ : PI 動作を表す伝達関数. 式 $(23) \sim(30)$ より, 給水流量 $g_{\mathrm{S}}$ の変化に対する $\mathrm{RD}$ 入, 出口温水温 度 $\theta_{\mathrm{RD}}^{\mathrm{W}, \text { in }}, \theta_{\mathrm{RD}}^{\mathrm{W}, \text { out }}$ の応答を表すブロック線図は図 3 で表される.

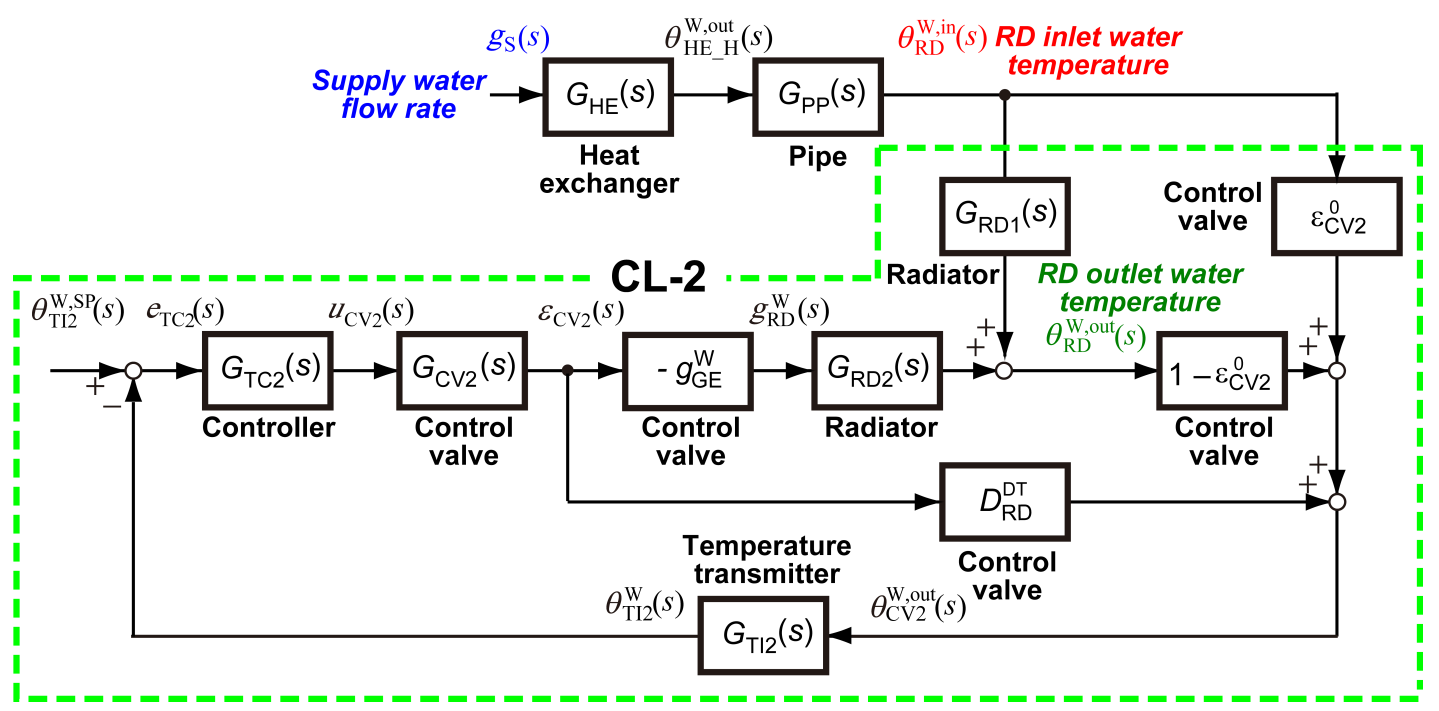

Fig. 3 Block diagram for response of radiator inlet and outlet temperatures to change in supply water flow 
これより, 次式で示す給水流量変化に対する RD 入, 出口温水温度の応答を表す伝達関数が得られる.

$$
\begin{aligned}
& \frac{\theta_{\mathrm{RD}}^{\mathrm{W}, \mathrm{in}}(s)}{g_{\mathrm{S}}(s)}=G_{\mathrm{HE}}(s) G_{\mathrm{PP}}(s) \\
& \frac{\theta_{\mathrm{RD}}^{\mathrm{W}, \text { out }}(s)}{g_{\mathrm{S}}(s)} \\
& =\frac{G_{\mathrm{HE}}(s) G_{\mathrm{PP}}(s)\left\{G_{\mathrm{RD} 1}(s)\left[1+D_{\mathrm{RD}}^{\mathrm{DT}} G_{\mathrm{TI} 2}(s) G_{\mathrm{TC} 2}(s) G_{\mathrm{CV} 2}(s)\right]+\varepsilon_{\mathrm{CV} 2}^{0} g_{\mathrm{GE}} \mathrm{W} G_{\mathrm{T} 2}(s) G_{\mathrm{TC} 2}(s) G_{\mathrm{CV} 2}(s) G_{\mathrm{RD} 2}(s)\right\}}{1+D_{\mathrm{RD}}^{\mathrm{DT}} G_{\mathrm{TI} 2}(s) G_{\mathrm{TC} 2}(s) G_{\mathrm{CV} 2}(s)-\left(1-\varepsilon_{\mathrm{CV} 2}^{0}\right) g_{\mathrm{GE}}^{\mathrm{W}} G_{\mathrm{TI} 2}(s) G_{\mathrm{TC} 2}(s) G_{\mathrm{CV} 2}(s) G_{\mathrm{RD} 2}(s)}
\end{aligned}
$$

給水流量変化に対する $\mathrm{RD}$ 出入口温水温度差 $\Delta \theta_{\mathrm{RD}}$ の応答を表す伝達関数は, 式（31），(32）より次式で表せる.

$$
\frac{\Delta \theta_{\mathrm{RD}}(s)}{g_{\mathrm{S}}(s)}=\frac{\theta_{\mathrm{RD}}^{\mathrm{W}, \text { out }}(s)-\theta_{\mathrm{RD}}^{\mathrm{W}, \text { in }}(s)}{g_{\mathrm{S}}(s)}=\frac{\theta_{\mathrm{RD}}^{\mathrm{W}, \text { out }}(s)}{g_{\mathrm{S}}(s)}-\frac{\theta_{\mathrm{RD}}^{\mathrm{W}, \text { in }}(s)}{g_{\mathrm{S}}(s)}
$$

式(8)より算出した給水流量変化（平衡点での給水流量は $70 \%$ ）に対する RD 出入口温水温度差の応答に関する 周波数特性を図 4 に示す. 伝達関数より算出した結果を実線で, また, プロセスシミュレータによる算出結果 (計 測値に相当）をプロットで示しており，両者が良好に一致していることを確認できる. 図より，給水流量変化に 対する $\mathrm{RD}$ 出入口温水温度差の応答は高次の遅れ特性を有しているが，低周波数域で RD 内の温水通過時間に起 因する遅れ特性が現れ，その他の機器による遅れ特性が高周波数域で現れている.

次に, 給水流量変化に対寸る $\mathrm{RD}$ 出入口温水温度差の忘答特性を一次遅れ系と近似して算出したカットオフ周 波数と正規化した給水流量の関係を図 5 に示す. カットオフ周波数は給水流量によって変化する RD 流入温水流 量の影響を受けるため, 図中のプロットで表寸算出值に対して実線で表す近似線 $f_{\mathrm{RD}}\left(g_{\mathrm{S}}\right)$ を同定する。これより, 時刻 $t$ における給水流量変化に対する $\mathrm{RD}$ 出入口温水温度差の応答時定数 $T_{\mathrm{RD}, t}[\mathrm{~s}]$ は次式で表せる.

$$
T_{\mathrm{RD}, t}=\frac{1}{2 \pi f_{\mathrm{RD}}\left(\bar{g}_{\mathrm{S}, t}^{\mathrm{M}}\right)}
$$

ここで, $\bar{g}_{\mathrm{S}, t}^{\mathrm{M}}$ : 時刻 $t$ における平均給水流量. これより, 動的補償を適用した時刻 $t$ における $\mathrm{RD}$ 出入口温水温度差 の推定值 $\Delta \theta_{\mathrm{RD}, t}^{\mathrm{E}}$ は, 式(3)に基づき次式で算出される.

$$
\Delta \theta_{\mathrm{RD}, t}^{\mathrm{E}}=\Delta \theta_{\mathrm{RD}, t-\Delta t}^{\mathrm{E}}+\left(\left.\Delta \theta_{\mathrm{RD}, t}^{\mathrm{S}}\right|_{\bar{g}_{\mathrm{S}, t}^{\mathrm{M}}}-\left.\Delta \theta_{\mathrm{RD}, t-\Delta t}^{\mathrm{S}}\right|_{\bar{g}_{\mathrm{S}, t-\Delta t}^{\mathrm{M}}}\right)\left(1-\mathrm{e}^{-\frac{\Delta t}{T_{\mathrm{RD}, t}}}\right)
$$

ここで, $\Delta \theta_{\mathrm{RD}, t}^{\mathrm{S}}$ : 時刻 $t$ における給水流量 $\bar{g}_{\mathrm{S}, t}^{\mathrm{M}}$ に応じた定常状態での $\mathrm{RD}$ 出入口温水温度差.

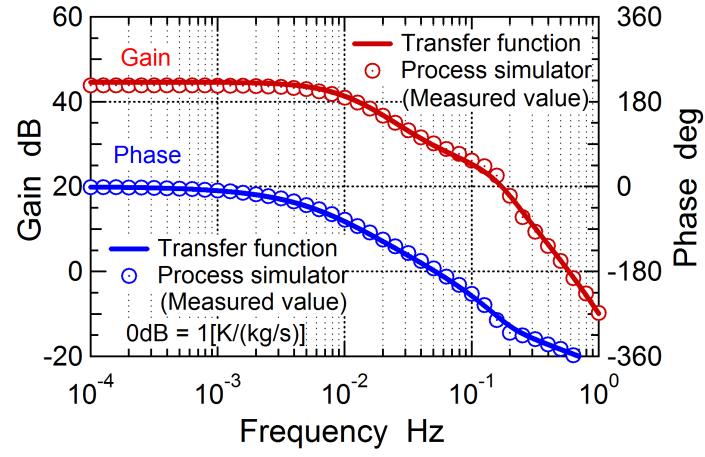

Fig. 4 Frequency characteristic of inlet-outlet water temperature difference of radiator to change in supply water flow rate

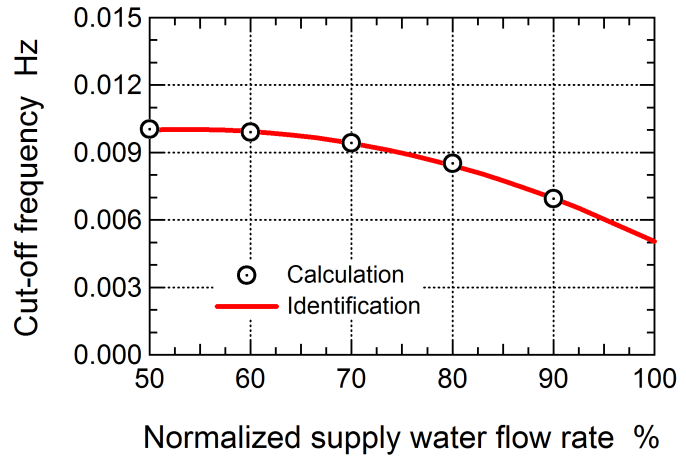

Fig. 5 Relationship between cut-off frequency and normalized supply water flow rate 


\section{$4 \cdot 3$ 監視条件}

入・出力プロセス值の測定を行うサンプリング時間は 1 秒とする. 平均化処理時間を長くすると測定值に含ま れるノイズの影響を低減できるが，運転条件の変化に伴う影響を把握しにくくなる，そこで，本論文では試行錯 誤的に平均化処理時間 $\Delta t$ を 60 秒に決定している. これより，入出力モデルおよび動的補償に基づく出力プロセ 值の推定，性能監視も 60 秒ごとに行うことになる. また， RD 出入口温水温度差に関しては，動的補償の効果 を明らかにするために, 動的補償を適用せずに入出力モデルのみで出力プロセス值を推定する場合も取り上げる. 後述するように, 対象プロセスが正常状態にあっても, 監視指標は給水流量の広範囲に渡る変化に伴い正常值 (1.0) から変動する．過渡的な正常値からの乘離で異常を誤検出しないように，一定期間（異常検出時間）に渡って監 視指標が閾値を越えた場合にプロセスに異常が発生したと見なし，異常検出時間は RD の整定時間（時定数の約 4 倍）よりも長く取ることとする. 図 5 と式（34）より，対象プロセスで応答が最も緩やかな RD の時定数は 30 秒程度になりうるため, 本論文では性能監視手法構築の第一段階として, いずれかの出力プロセス値の監視指標 が 5 分間連続して閾值を超えた場合に，機器に異常が発生したものと判断する. 閾值は次章に示す正常状態での 監視を通して決定する．なお，対象プロセスでは機器異常が突発的に生じることも考えられる．その場合，短時 間の内にプロセス值に大きな影響が現れるため，プロセス值の上，下限值への到達を監視することで対応し，本 論文では比較的長い時間スケールで生じる機器異常に着目する.

\section{5. 正常状態での監視}

対象プロセスが正常状態にある場合の性能監視を行い，構築した動的補償の有効性を検証するとともに，機器 異常検出のための監視指標の閾値を設定する．給水流量が一定の定常状態下では測定值（プロセスシミュレータ

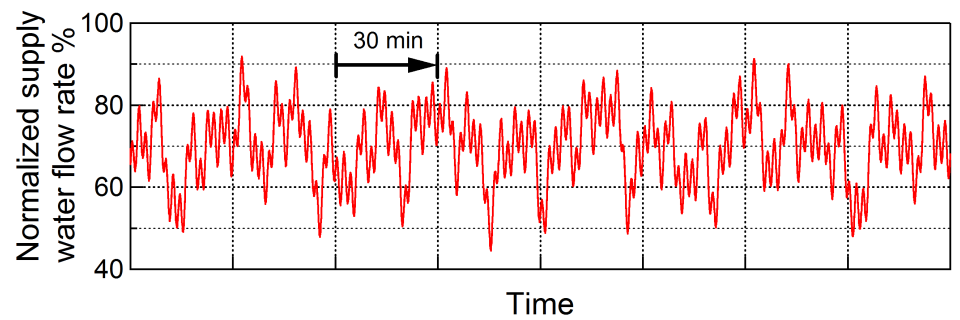

(a) Normalized supply water flow rate

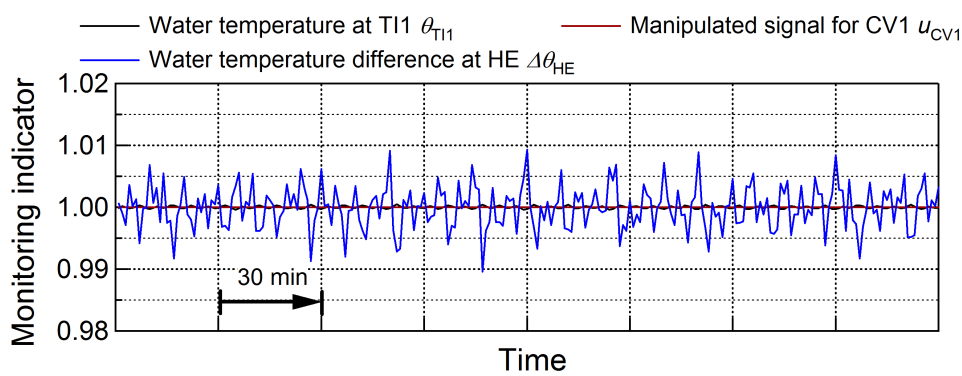

(b) Monitoring indicators in CL-1

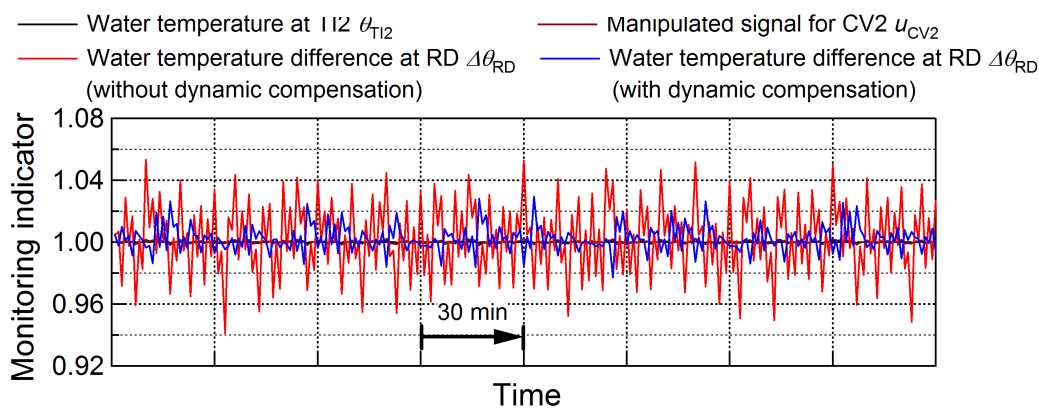

(c) Monitoring indicators in CL-2

Fig. 6 Monitoring result of target heat utilization process under normal operating condition 
出力）と入出力モデルによる推定值が良好に一致寸ることを確認しているため，ここでは，給水流量が不規則的 に変化する動的状態に着目する.

性能監視結果として, 給水流量の時間変化, 平均化処理時間ごとに算出される温度制御ループ CL-1 およびCL-2 における監視指標を図 6 に示す．いずれの監視指標も給水流量の広範囲に渡る変化に伴い正常值（1.0）から変動 しているが，変動の大きさは出力プロセス值により異なっている．RD 出入口温水温度差以外の出力プロセス值 は定常特性に着目した入出力モデルのみを用いて推定を行っているため, 応答の時間遅れの比較的大きな HE 出 入口温水温度差で変動が大きくなるが，最大偏差は土 $1 \%$ 程度である. また, $\mathrm{RD}$ 出入口温水温度差については, 入出力モデルのみで推定を行った場合の監視指標よりも，動的補償を適用した場合の監視指標の方が正常値から の変動が小さくなっており，測定值を動的状態下で良好に推定できていることがわかる．これは給水流量が多い （RD への流入温水流量が少ない）時により顕著になる. 動的補償を適用しない場合の $\mathrm{RD}$ 出入口温水温度差に ついての監視指標の最大偏差は土6\%程度であるのに対して, 動的補償を適用した場合の最大偏差は土3\%程度に 抑えられている.

各出力プロセス值の監視指標に設定する閾值は, 表 3 に示すように, 図 6 における正常值からの最大偏差の 1.2 倍とする. 本論文で設定した計算条件では HE 出口温水温度が設定值よりも常に高いため, 調節弁 CV1 の操作信 号は 100\%で固定される．よって，調節弁 CV1 の操作信号に対する閾值の設定は行わないこととする.

Table 3 Thresholds for detecting device failures

\begin{tabular}{|c|l|c|c|}
\hline $\begin{array}{c}\text { Control } \\
\text { loop }\end{array}$ & \multicolumn{1}{|c|}{ Output process variables } & $\begin{array}{c}\text { Maximum } \\
\text { deviations \% }\end{array}$ & Thresholds \% \\
\hline \multirow{3}{*}{ CL-1 } & Water temperature at TI1 & 0.050 & 0.060 \\
\cline { 2 - 4 } & Manipulated signal for CV1 & 0.0 & - \\
\cline { 2 - 4 } & Water temperature difference at HE & 1.0 & 1.2 \\
\hline \multirow{4}{*}{ CL-2 } & Water temperature at TI2 & 0.052 & 0.062 \\
\cline { 2 - 4 } & Manipulated signal for CV2 & 0.24 & 0.29 \\
\cline { 2 - 4 } & Water temperature difference at RD (with dynamic compensation) & 2.9 & 3.5 \\
\cline { 2 - 4 } & Water temperature difference at RD (without dynamic compensation) & 5.9 & 7.1 \\
\hline
\end{tabular}

\section{6. 機器異常時の監視}

\section{$6 \cdot 1$ 機器異常のモデル化}

対象プロセスの制御対象である RD および HE に異常が発生した場合の動的状態下での性能監視を行う. RDで 発生しうる異常として，空気中の污れがフィンに付着して伝熱性能が低下した場合に着目する. プロセスシミュ レータにおける RD の熱通過率 $K_{\mathrm{RD}}$ の算出式を式 (13) から次式に変更し, 污れ係数 $R_{\mathrm{F}}\left[\mathrm{m}^{2} \cdot \mathrm{K} / \mathrm{W}\right]$ を時間の経過 とともに初期值より線形に増加させることで, 見かけの空気側（フィン側）の熱伝達率 $\alpha_{\mathrm{RD}}^{\mathrm{A}, \mathrm{AP}}\left[\mathrm{W} /\left(\mathrm{m}^{2} \cdot \mathrm{K}\right)\right]$ を低下 させる(22).

$$
\left.\begin{array}{l}
K_{\mathrm{RD}}=\frac{1}{A_{\mathrm{RD}}}\left[\frac{1}{\alpha_{\mathrm{RD}}^{\mathrm{A}, \mathrm{AP}}\left(A_{\mathrm{T}}^{\mathrm{A}}+\phi_{\mathrm{F}} A_{\mathrm{F}}\right)}+\frac{1}{\alpha_{\mathrm{RD}}^{\mathrm{W}} \mathrm{A}_{\mathrm{T}}^{\mathrm{W}}}\right]^{-1} \\
\alpha_{\mathrm{RD}}^{\mathrm{A}, \mathrm{AP}}=\left[\frac{1}{\alpha_{\mathrm{RD}}^{\mathrm{A}}}+R_{\mathrm{F}}\right]^{-1}
\end{array}\right\}
$$

また, HE で発生しうる異常として, 給水中の污れがプレートに付着して伝熱性能が低下した場合に着目する. プロセスシミュレータにおける $\mathrm{HE}$ の熱通過率 $K_{\mathrm{HE}}$ の算出式を式 (9) から次式に変更し, 污れ係数 $R_{\mathrm{P}}\left[\mathrm{m}^{2} \cdot \mathrm{K} / \mathrm{W}\right]$ を時間の経過とともに初期值より線形に増加させることで，見かけの低温側熱伝達率 $\alpha_{\mathrm{HE}}^{\mathrm{L}, \mathrm{AP}}\left[\mathrm{W} /\left(\mathrm{m}^{2} \cdot \mathrm{K}\right)\right]$ を低下さ せる(16). 


$$
\left.\begin{array}{l}
K_{\mathrm{HE}}=\left[\frac{1}{\alpha_{\mathrm{HE}}^{\mathrm{H}}}+\frac{t_{\mathrm{P}}}{\lambda_{\mathrm{P}}}+\alpha_{\mathrm{HE}}^{\mathrm{L}, \mathrm{AP}}\right]^{-1} \\
\alpha_{\mathrm{HE}}^{\mathrm{L}, \mathrm{AP}}=\left[\frac{1}{\alpha_{\mathrm{HE}}^{\mathrm{L}}}+R_{\mathrm{P}}\right]^{-1}
\end{array}\right\}
$$

\section{$6 \cdot 2$ RD の伝熱性能低下時の監視}

$\mathrm{RD}$ の伝熱性能が低下した時の性能監視結果として，平均化処理時間ごとに算出される RD 出入口温水温度差 および温度制御ループ CL-1，CL-2 で得られる監視指標を図 7 に示す. 給水流量の変化は図 6 と同様であり，図 中破線時より, $\mathrm{RD}$ の污れ係数が $4.0 \times 10^{-6} \mathrm{~m}^{2} \cdot \mathrm{K} /(\mathrm{W} \cdot \mathrm{s})$ ずつ増加している. 図 7(a)より, $\mathrm{RD}$ 出入口温水温度差は 給水流量の変化により大きく変化するため, 測定した $\Delta \theta_{\mathrm{RD}}^{\mathrm{M}}$ の監視だけでは $\mathrm{RD}$ の性能低下を検出することは困難 である.しかし, 推定值 $\Delta \theta_{\mathrm{RD}}^{\mathrm{S}}$ おび $\Delta \theta_{\mathrm{RD}}^{\mathrm{E}}$ と比較すると, $\Delta \theta_{\mathrm{RD}}^{\mathrm{M}}$ は時間の経過とともに $2 つ の$ 推定值に比べて低下 していくことがわかる．次に，図 7(c)に示す温度制御ループCL-2 における監視指標に着目する. RD 出入口温水

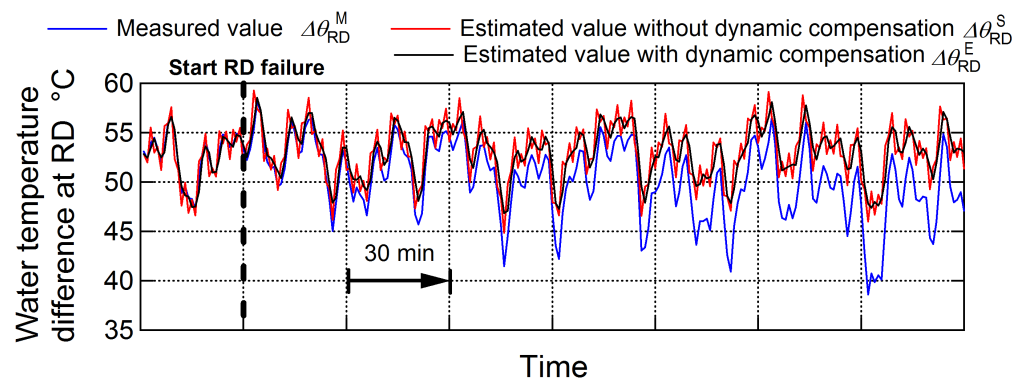

(a) Measured and estimated water temperature differences at RD

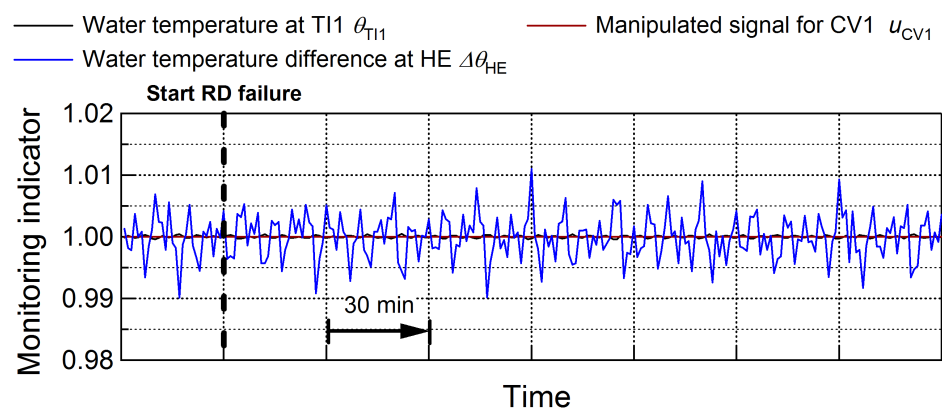

(b) Monitoring indicators in CL-1

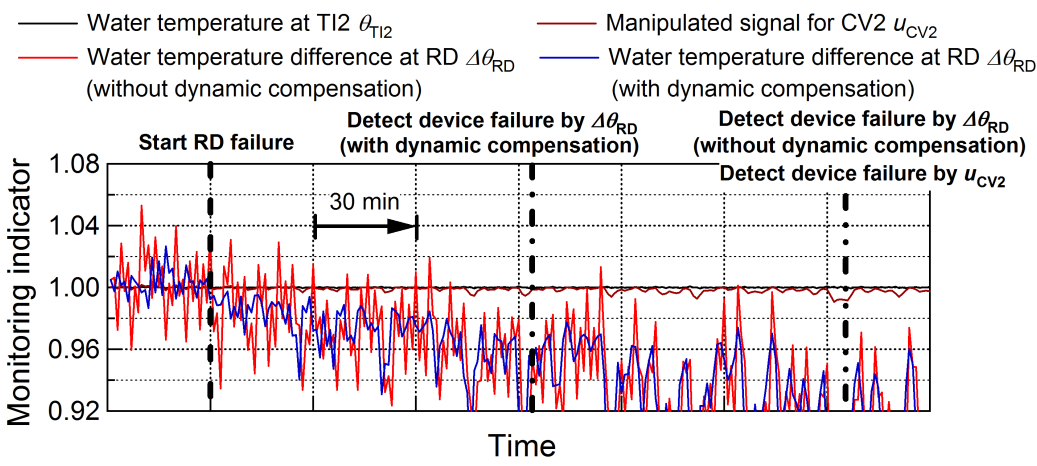

(c) Monitoring indicators in CL-2

Fig. 7 Monitoring result of target heat utilization process under RD failure condition 
温度差についての監視指標は動的補償の有無によらず時間の経過とともに減少していくが，動的補償を適用する ことで監視指標の変動が大幅に抑制されることがわかるそその結果，動的補償を適用した場合には伝熱性能の低 下が始まってから 94 分後（図中，一点鎖線）に異常を検出できるのに対して，動的補償を適用しない場合には 185 分後（図中，二点鎖線時）に異常を検出することになる．また，伝熱性能の低下によって調節弁 CV2 の操作 信号についての監視指標も低下しており, 動的補償を適用しない RD 出入口温水温度差と同様に 185 分後 (図中, 点線時）に異常を検出している，これは RD の伝熱性能が低下するのに対して，RDへの流入温水流量を増やす ことで温度伝送器 TI2 での測定温水温度を目標值に保持するためである. さらに, 図 7(b)より, RD の伝熱性能が 低下しても温度制御ループ CL-1 における監視指標には異常が現れないことがわかる. 温度制御ループ CL-2 の制 御動作により, RD の伝熱性能が低下しても温度伝送器 T12 での測定温水温度（熱源への戻り温度）は目標值に 保たれることから，温度制御ループ CL-1 には RD の伝熱性能低下の影響が現れない.

\section{6・3 HE の伝熱性能低下時の監視}

$\mathrm{HE}$ の伝熱性能が低下した時の性能監視結果として, 平均化処理時間ごとに算出される HE 出入口温水温度差お よび温度制御ループ CL-1，CL-2 で得られる監視指標を図 8 に示す. 給水流量の変化は図 6 と同様であり, 図中

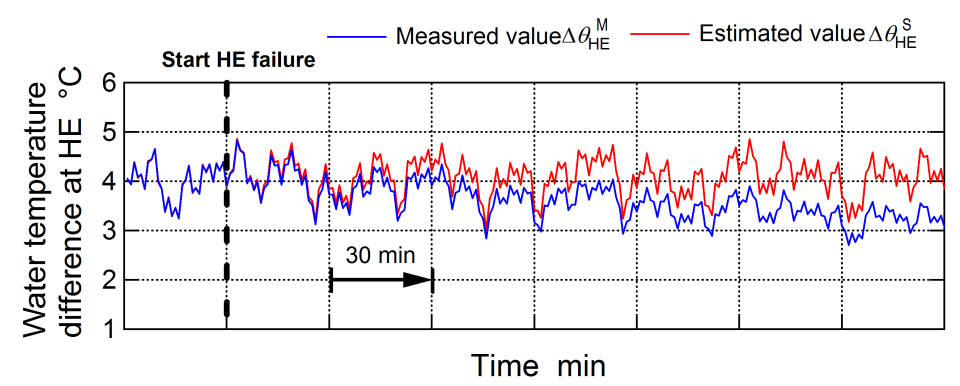

(a) Measured and estimated water temperature differences at $\mathrm{HE}$

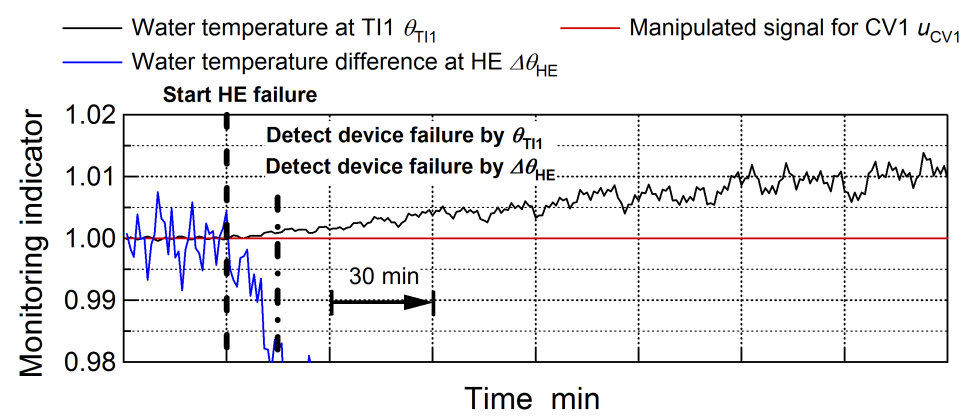

(b) Monitoring indicators in CL-1

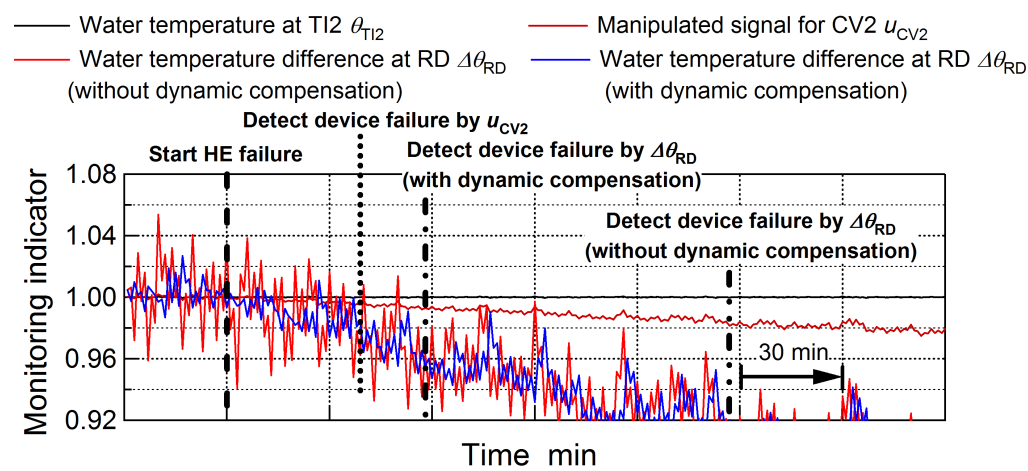

(c) Monitoring indicators in CL-2

Fig. 8 Monitoring result of target heat utilization process under HE failure condition 
破線時より $\mathrm{HE}$ の污れ係数が $3.0 \times 10^{-9} \mathrm{~m}^{2} \cdot \mathrm{K} /(\mathrm{W} \cdot \mathrm{s})$ ずつ増加している. $\mathrm{HE}$ 出入口温水温度差の測定值 $\Delta \theta_{\mathrm{HE}}^{\mathrm{M}}$ は給水 流量の変化により大きく変化するが, 伝熱性能の低下が進むと推定值 $\Delta \theta_{\mathrm{HE}}^{\mathrm{S}}$ に比べて減少していくことがわかる. 図 8(b)に示寸温度制御ループ CL-1 における監視指標に着目寸ると，伝熱性能の低下が始まってから 15 分後（図 中，一点鎖線）に HE 出入口温水温度差の低下を検出している．また，温度伝送器 TI1 での測定温水温度につい ての監視指標の増加も同時に検出される. 一方，図 8(c)に示寸温度制御ループ CL-2 に関しては, RD 出入口温水 温度差の監視指標が低下していくが，動的補償を適用することでより早く異常を検出できることがわかる．さら に，調節弁 CV2 の操作信号についての監視指標も低下していくことから，温度制御ループ CL-2 に関する監視指 標は，RD（図 7）と HE（図 8）の伝熱性能低下に対して同じ傾向変動を示すことになる。しかし，温度制御ルー プ CL-1 に関する監視指標の傾向変動は図 7 と図 8 で大きく異なることから, RD と HE で生じた伝熱性能の低下 を区別することができる.

実際に生じる伝熱性能の低下は非常に長い時間スケールで進行すると考えられる．しかし，污れ係数の増加速 度をごく緩やかにした上で性能監視を行った場合でも, 動的補償を適用することで監視指標の閾值が小さくなり, 機器異常をより早く検出できることを確認している．また，結果は示していないが，制御対象以外の機器に異常 が生じた場合にも本性能監視手法により検出できることを併せて確認している.

\section{7. 結言}

複数の機器と温度制御ループから構成される分散型エネルギーシステムの熱利用プロセスに対して, 動的状態 に対応したモデルベース性能監視手法を構築した。 これまでに構築したモデルベース性能監視手法(13)では, 性能 監視間隔（測定したプロセス值の平均化処理時間に相当）ごとに入力プロセス值に応じた定常状態での出力プロ セス值を入出力モデルを用いて推定しているが，熱利用プロセスでは時間遅れの大きな出力プロセス值が存在し うる. そこで, 対象プロセスの時間遅れ特性を一次遅れ系で近似し, 性能監視間隔分の応答の時間遅れを入出力 モデルで推定した出力プロセス值に反映させる動的補償を新たに導入した．民生用ガスエンジンコージェネレー ションシステムを対象とした数值シミュレーションによるケーススタディを通して, 動的補償を導入することで 応答の時間遅れが大きなラジェータの出入口温水温度差を動的状態下で良好に推定できるようになり, 機器異常 を検出するための監視指標の閾值を小さくできることがわかった，その結果，動的状態下でラジエータの伝熱性 能が低下した場合に，より早期にその異常を検出できることを明らかにした．また，本モデルベース性能監視手 法は, 制御対象であるラジエータと熱交換器で生じた伝熱性能の低下を区別できることから, その有効性を示寸 ことができたと考える.

動的補償を用いた出力プロセス值の推定は, 性能監視間隔（本論文では 60 秒）ごとに行うため, リアルタイム で動的シミュレーションを行って対象プロセスの挙動を把握する必要がなく, 制御システムへの追加実装に際し て演算負荷の増加を抑えることができる. また，入出力モデルでは構成機器をモジュール結合することにより非 線形連立代数方程式を得るため, 機器構成が変化した場合への適用が容易である. さらに, 動的補償は応答の時 間遅れが大きな機器にのみ適用寸れば良く, また, 一次遅れ系として近似した場合の応答時定数も周波数特性よ り算出できる. よって, 本論文で構築したモデルベース性能監視手法はその他の熱利用プロセスにも十分適用で きると考える. しかし，入力プロセス值である外気温および給水温度は 1 日あるいは 1 年周期で変化すること， さらには, 温度制御ループ CL-1 の制御動作が行われる運転条件については検討していないことから, 計算条件 を拡張したケーススタディを進める必要がある. また, より早く機器異常を検出するために監視条件の最適化を 行うことも重要である. その上で, 実機にて有効性の検証を行うとともに, 異常が発生した機器の特定（診断機 能）についても検討を行う予定である.

\section{文献}

（1）横山良平, 伊東弘一, "エネルギー供給システムの運用マネジメントのための最適化手法の総合的活用”, 日本 機械学会第 15 回環境工学総合シンポジウム 2005 講演論文集, (2005), pp. 445-446.

(2) Venkatasubramanian, V., Rengaswamy, R., Yin, K., and Kavuri, S. N., "A Review of Process Fault Detection and Diagnosis. Part I: Quantitative Model-based Methods", Computers \& Chemical Engineering, Vol. 27, No. 3 (2003), pp. 293-311. 
(3) Venkatasubramanian, V., Rengaswamy, R., and Kavuri, S. N., "A Review of Process Fault Detection and Diagnosis. Part II: Qualitative Models and Search Strategies", Computers \& Chemical Engineering, Vol. 27, No. 3 (2003), pp. 312-326.

(4) Venkatasubramanian, V., Rengaswamy, R., Kavuri, S. N., and Yin, K., "A Review of Process Fault Detection and Diagnosis. Part III: Process History Based Methods", Computers \& Chemical Engineering, Vol. 27, No. 3 (2003), pp. 327-346.

(5) Cho, S. H., Yang, H. C., Zaheer-uddin, M., and Ahn, B. C., "Transient Pattern Analysis for Fault Detection and Diagnosis of HVAC Systems", Energy Conversion and Management, Vol. 46, No. 18 (2005), pp. 3103-3116.

(6) Hou, Z., Lian, Z., Yao, Y., and Yuan, X., "Data Mining Based Sensor Fault Diagnosis and Validation for Building Air Conditioning System", Energy Conversion and Management, Vol. 47, No. 15 (2006), pp. 2479-2490.

(7) Biagetti, T. and Sciubba, E., "Automatic Diagnostics and Prognostics of Energy Conversion Process via Knowledge-based Systems", Energy, Vol. 29, No. 12 (2004), pp. 2553-2572.

(8) Wang, S. and Xiao, F., "Detection and Diagnosis of AHU Sensor Fault Using Principal Component Analysis Method", Energy Conversion and Management, Vol. 45, No. 17 (2004), pp. 2667-2686.

(9) 田村雅之, ”プラント起動時における経験的診断ロジックの動的時間伸縮法による設計法”, 日本機械学会論文集 C 編, Vol. 76, No. 767 (2010), pp. 1649-1654.

(10) Kim, S. M. and Joo, Y. J., "Implementation of On-line Performance Monitoring System at Seoincheon and Sinincheon Combined Cycle Power Plant", Energy, Vol. 30, No. 13 (2005), pp. 2383-2401.

(11) Takahashi, T., Koda, E., and Nakao, Y., "Development of Performance Deterioration Diagnosis Method for Gas Turbine Combined Cycle Power Plants", Journal of Power and Energy Systems, Vol. 5, No. 3 (2011), pp. 249-262.

(12) Umezawa, S., "Performance Diagnosis using Optical Torque Sensor for Selection of a Steam Supply Plant among Advanced Combined Cycle Power Plants", Journal of Power and Energy Systems, Vol. 2, No. 3 (2008), pp. 956-964.

(13) Wakui, T. and Yokoyama, R., "On-line Model-based Performance Monitoring of a Shell-and-tube Type Heat Exchanger Using Steam and Water", Energy Conversion and Management, Vol. 49, No. 10 (2008), pp. 2669-2677.

(14) Wakui, T., Nakamoto, H., and Yokoyama, R., "Model-based Performance Monitoring of Heat Exchange Process in Transient State", Journal of System Design and Dynamics, Vol. 3, No. 6 (2009), pp. 986-998.

（15）伊東弘一，横山良平，斯波敬，林秀和，“ガスエンジン・コージェネレーション・システムの動特性分析”，日本 機械学会論文集 C 編, Vol. 59, No. 559 (1993), pp. 807-813.

(16) 吉田邦夫，吉田英夫編，熱交換器ハンドブック，省エネルギーセンター, (2005), p. 95.

(17) 日本機械学会編, 伝熱工学資料, 改訂第 5 版, (2009), pp. 228-229.

(18) 日本機械学会編, 伝熱工学資料, 改訂第 5 版, (2009), p. 46.

(19) マイクロコージェネレーションシステム CP25VB 設備設計資料，ヤンマーエネルギーシステム， (2006)，pp.9-42.

(20) 横山良平, 大瀬脩平, 涌井徹也, ”太陽電池を併設したガスエンジンコージェネレーションシステムの最適運用計 画（運用方策および省エネルギー性に関する分析）”，日本機械学会第 21 回環境工学総合シンポジウム 2011 講 演論文集，(2011), pp. 272-275.

(21) Amano, Y., Yaegashi, S., Hashizume, T., and Machiyama, T., "Dynamic Characteristics of Two Shell-and-tube Heat Exchangers Connected in Parallel", Proceedings of the 1995 Joint Power Generation Conference, Vol. 3 (1995), pp. $79-85$.

(22) 日本機械学会編, 熱交換器の熱的設計法, (1996), p. 25. 